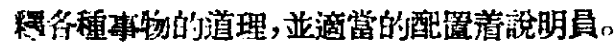

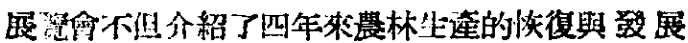

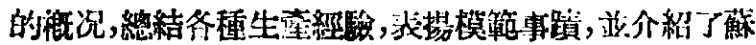

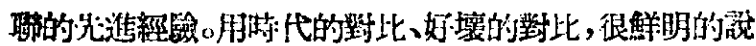

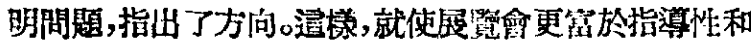

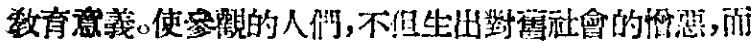

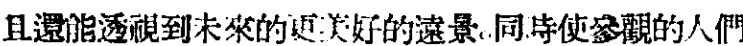

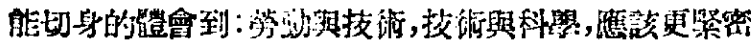
的秙合起來的必㴖。

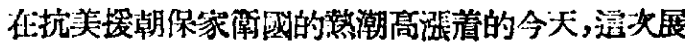

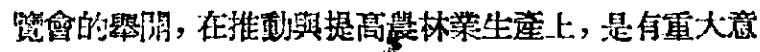
武的。

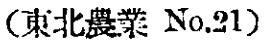

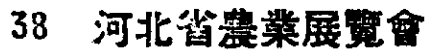

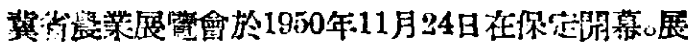

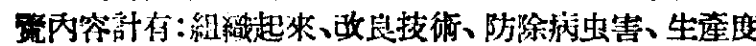

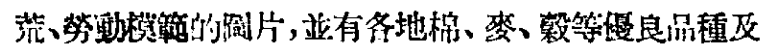

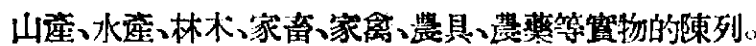
证設服務部利售品部。（交物教資料 No.11）

\section{9 山西省譩業全産展覽合}

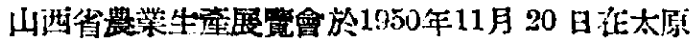

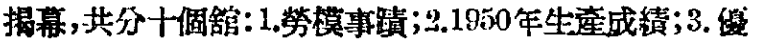

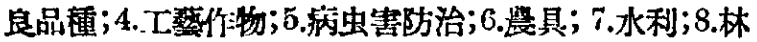

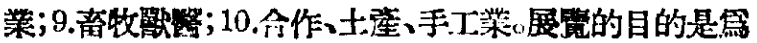

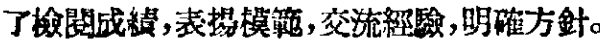

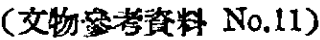

\section{0 揟克文化代表国訪問中國科 院}

揵克文化代表團在1月12日下午訪間中國科照院考 古研究所，並数了菠所的圆書頡。

\section{1 科㖒科普㖒合歡迎郭沫若及 出席和大代表}

中苼全國自然科學專門盟會聯合會及中華全國科

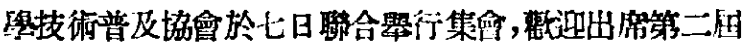

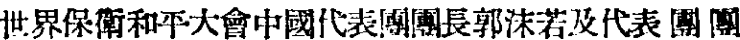

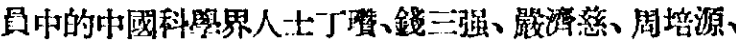

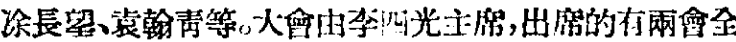

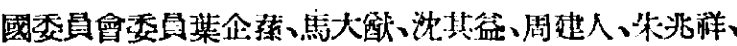

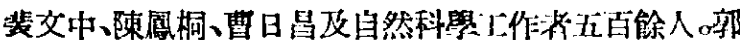

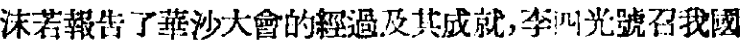

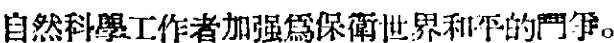

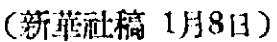

\section{2 中國科學院蜜㵧兩區熱烈歡 迎趙忠荰}

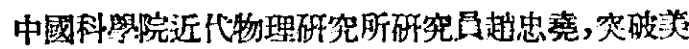

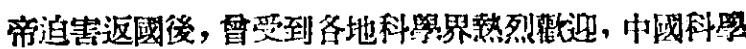
院.上海、南尔齐研究所面分別舉行慰問越教授，支控诉美 帝暴行大會。

(硕)

\section{3 越忠堯数授抵京}

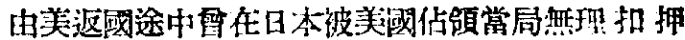

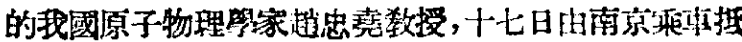
京。

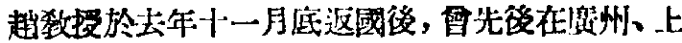

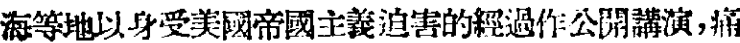

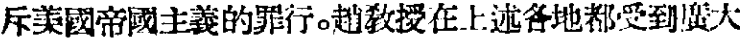
露案的敬迎。

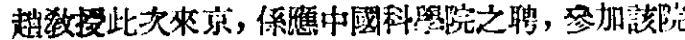
近代物理研究所，從事原子核研究工工作。

(新華征稿 1月18日)

\title{
國外之 部
}

\section{1 策䬼航空買創飛行速度的世 界新紀錄}

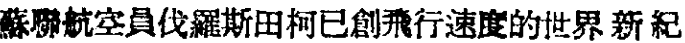

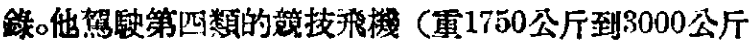
），每小特本均飛行 441公里又176公尺。代羅斯田柯是用 第二数榌機作1000公里飛行的径界速度紀銠保持者。他

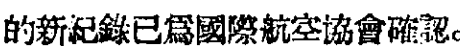

(新萑社稿 1月4日)

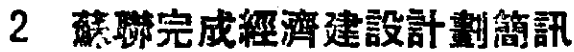

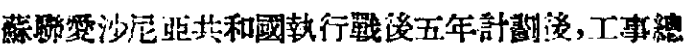

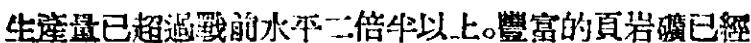

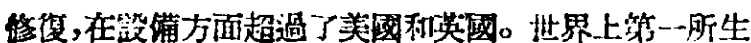

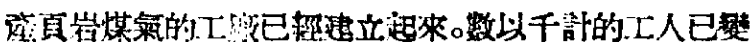

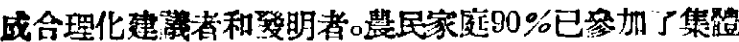

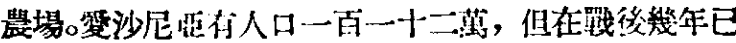

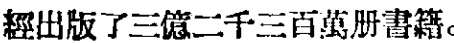

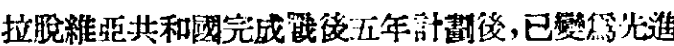

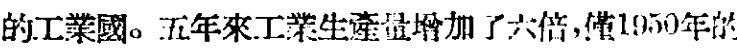

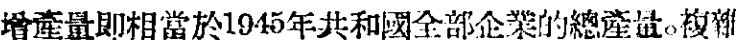

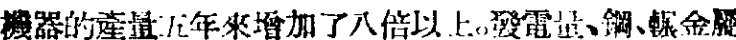

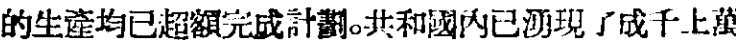

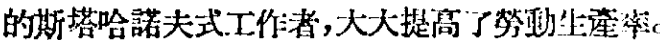

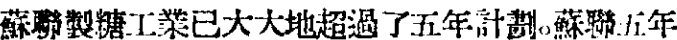

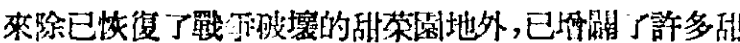

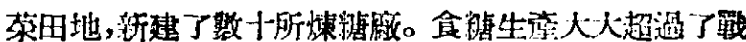

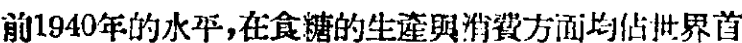
位。

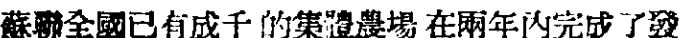




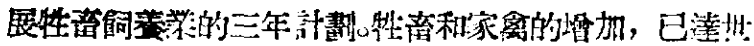
界上各國從來末有的速度、在1950年，牛的碩數增加了

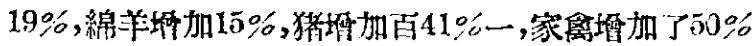

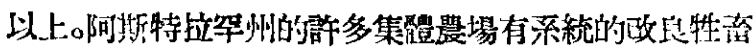
品種後,已能在每一䫄綿羊身上剪下七公厅至十公斤的

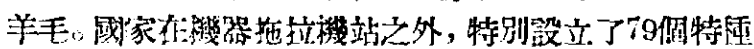

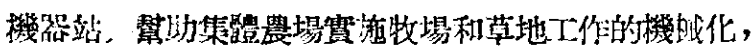

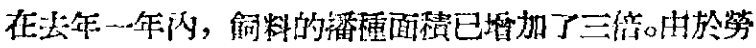

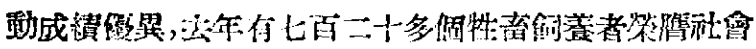

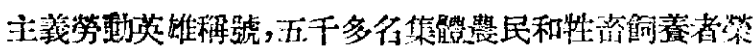
膺政泭㩆音。

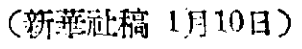

\section{3 蘇石油工業已提前完成五年 計䇏}

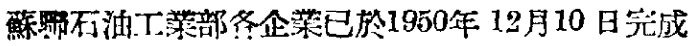

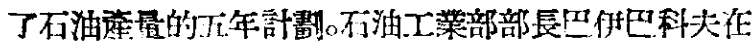

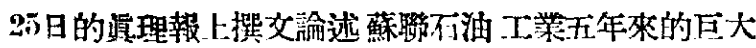
成就称: 蘇称許多不油托拉斯, 如古比霡夫、克拉斯渃 洼、士管曼及格羅斯尼的托拉斯，早在1949年就已完成

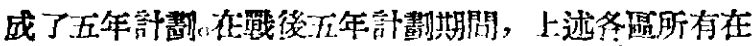

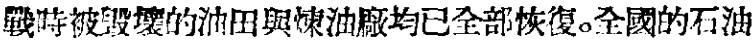

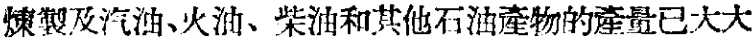

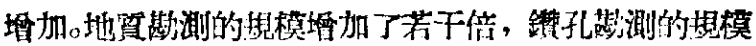
增至五倍以上。遥㑊得若干加盟共和國和州區, 特別是

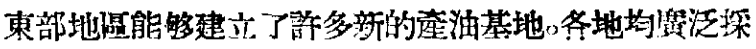

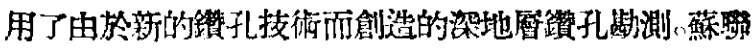

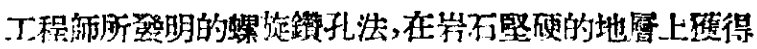

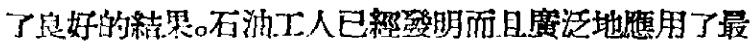

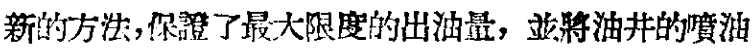
期一直保持到泊藏被探歩澡止。

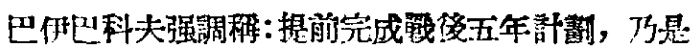

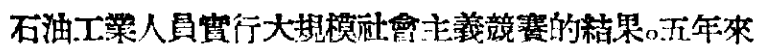

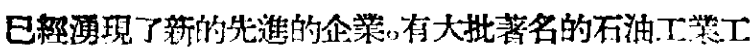

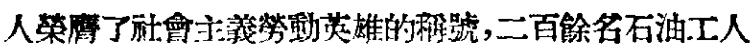

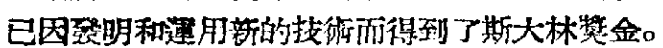

(彩葬社稿 1950.12.30.)

\section{4 策䎸政府决定加速建造伏露 加河一一頓河運河}

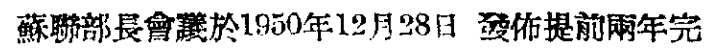
成仭爾加河一一出河運河的工程，及加速進行羅斯多夫 和斯入林格勒雨州的水利被溉丁程的决定。决定称：伏

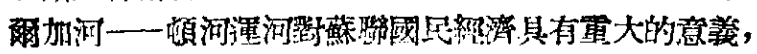
它將把在蕉距歐洲部分的白海、波羅的海、赛海、黑海和

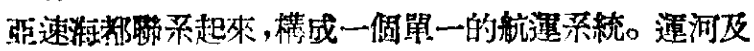
其分支上的水利厂程,將濯溉七十五营公頃土地, 並將

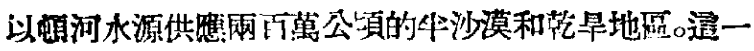
互大工程会因嘎等中止，但在三年前政府即通過决定快

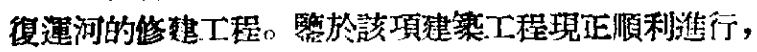

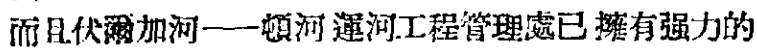

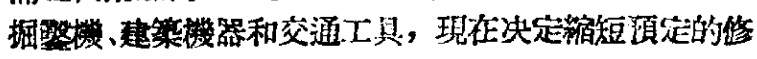

築期限兩年。

决定提定在1951年 完成從斯大林格勒诚到頓河傍 卡拉冾鐏的速接 伏爾加河與頓河的辰澾 101 公里的運

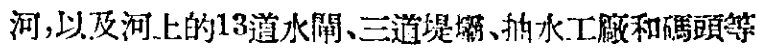
工程; 在頓河的济姆良斯卡雅村附近建恣一個谷水一百

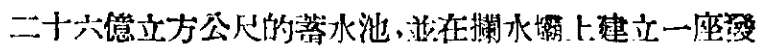

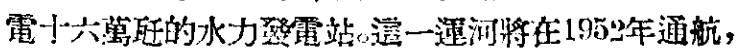
水電站方將在同将開始發電，

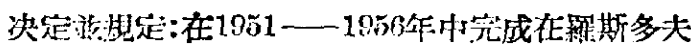

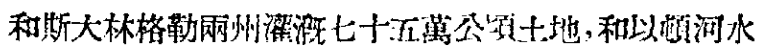

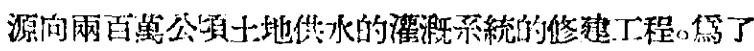

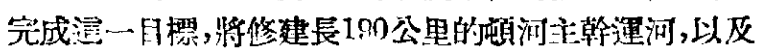

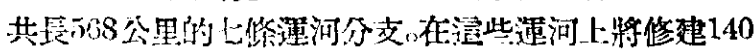

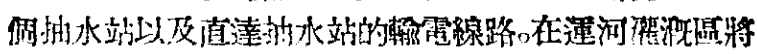

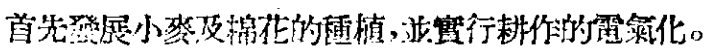

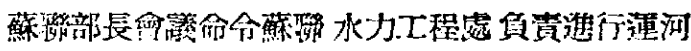

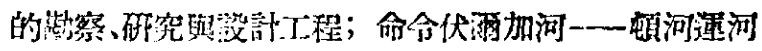

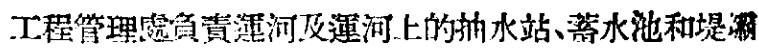

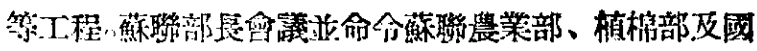

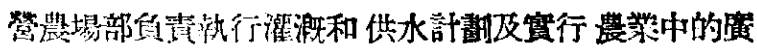
泛雷氣化的工作，㑇責與供水工程有閔的水電工程的

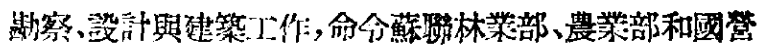

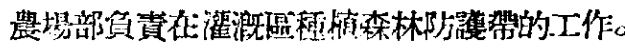

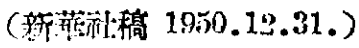

\section{5 向是竾進軍保障收成}

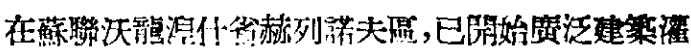

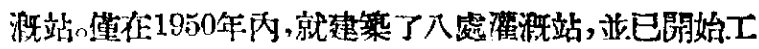
作。造些灌溉站在提高收腾察上起了不少的作用。揬照

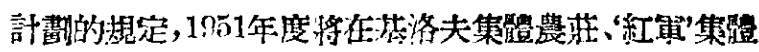

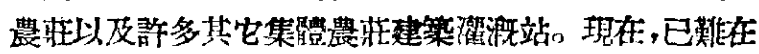

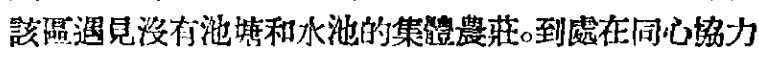
地僬行着植樹造林工作。在觜現政造自然的獍大斯大林

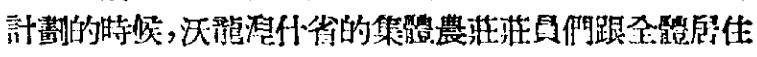

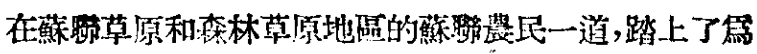

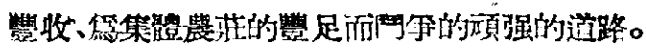

(乘北㩆樊 No.21)

\section{6 每小時灌1,200立方公尺水泥}

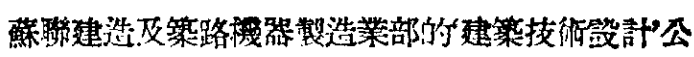

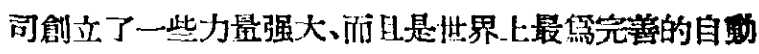
化的三合土水泥工筬。

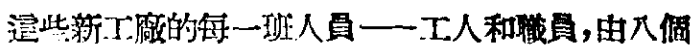

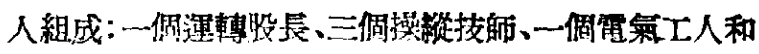

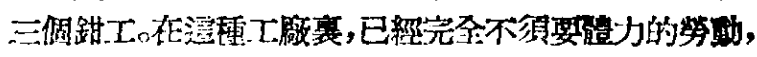
一切工作在此地然由機践和自䣦機:去完成。

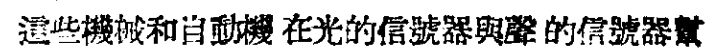
助之下，傳報仙三合土坑的某一個小合寒已程计清了，

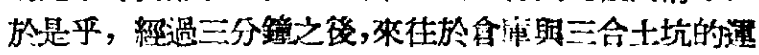
运機，就一車一車的裝着水泥、沙子或小石子，把涪一個

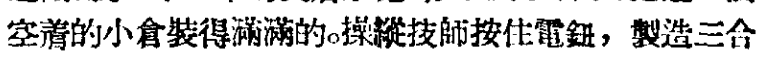
土所需要的材料,就自動選㛙好，稱好纷量，一事一耷的 


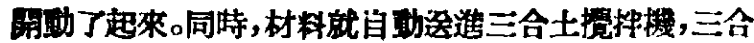

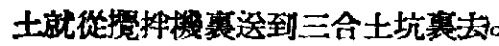

在這所巨大的完全是機㑘化的自動工野裏，一切.工 作過程的時間教是以秒來計算好的:称材料軍量的過程

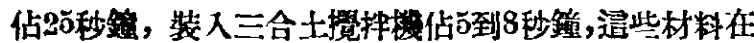

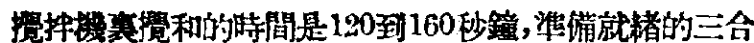

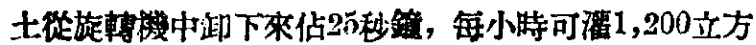
公尺的水泥。

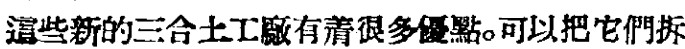

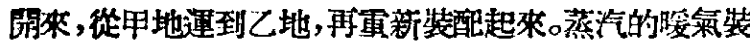

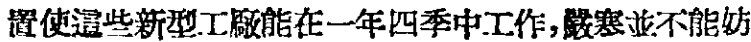
碍它們工作。钎多特殊的通風設備使得生迹的場所合乎 衛生,通些設供在吸收糜埃。

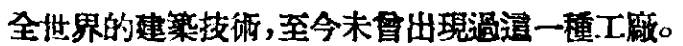
(资絬報 1月10日)

\section{7 開路吊土杫}

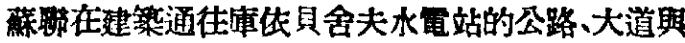

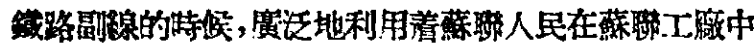
創造出來的最新式的機㳦興機器。

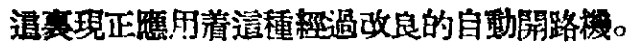

每一架自動開路校能做 300-350 個腒土工人的工 作。布良斯克工歌首先在國內開始生荤遥種强有力的開

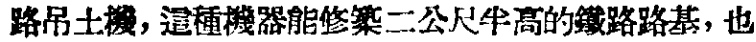
能完成䚺多別的倜土工作。式栐最新的䩼渠城土機，能

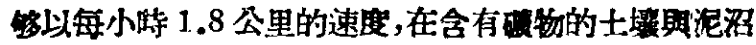

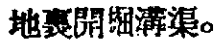

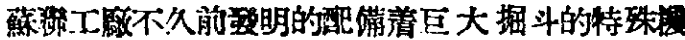
器, 如今已在各储新的建策工程中大規䫅的進行㨄土工 作。

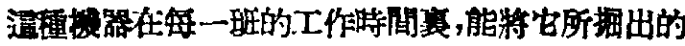
400到500立方公尺泥土運送到150公尺以外去。

（寅話報 1月10日）

\section{8 独聊自動步行掘㹂機}

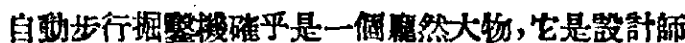

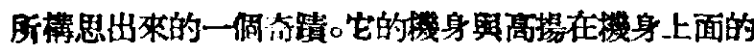

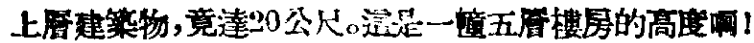
巨大的掘斗,一下子就能掘出 12致14立方公尺的泥土。

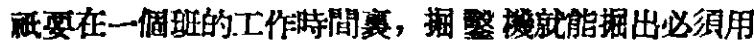
690 節事皮來装载的泥士。

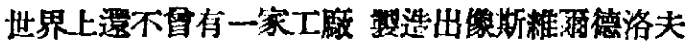

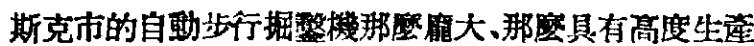

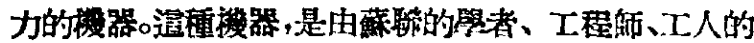

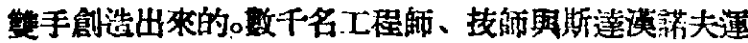

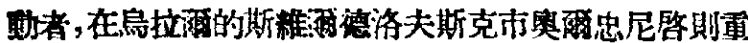

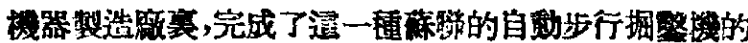
各種圆表和生尔技術過程。

（实話報 1月10日）

\section{9 打石聯合被}

直到現在，建築用石材僄是手工開琛。㓮㓮不久能，

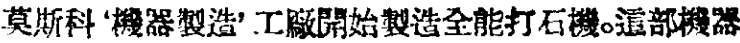

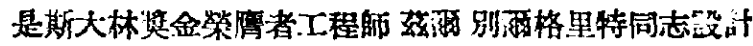
的。

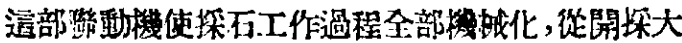
塊的塊狀岩的石頚，到運輸和乘截不站。它在八小時內， 能打出三百立方公尺的石頭。

（筫話報 1 月4日）

\section{0 精確到百萬分之一公分 的天秤}

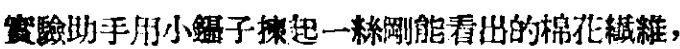

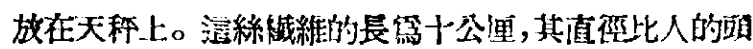

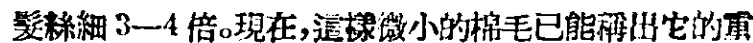
量。

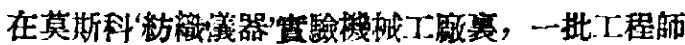
和技師設計出能程百萬分之一公分的精確天称。

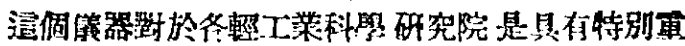

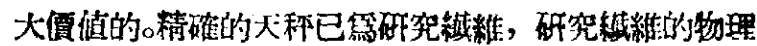
機峨特性開閶了新道路。

（惯話報 1月4日）

\section{1 磄坑用新式電話機}

救濩恅的工作人員篇了在地下通訊，使用一種 專門的電話機。

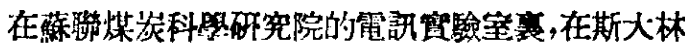

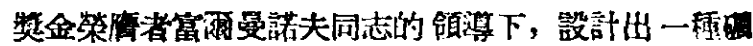
坑用新式電話機。它可以代替鹪式的㩲染不方便的電話 機。

遙種電話璣的軍量，比過去的電話機制十倍，其大

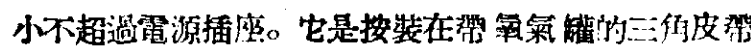

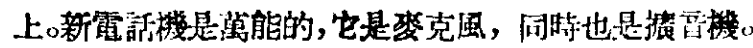

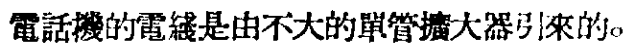

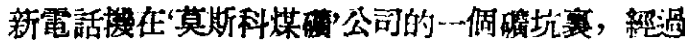
多方面試驗的結果，成續很好。

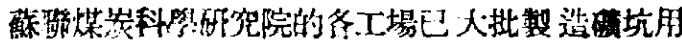
新式電話极。

(潩話者 1月4日)

\section{2 萧西的 3HM 牌新汽車}

莫斯科的街道上出現了一種 很漂堂的流影型小汽 車。汽車的放熱器上寒着“3

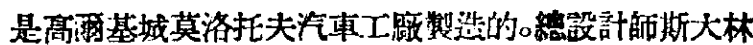

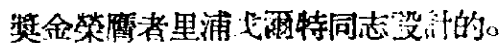

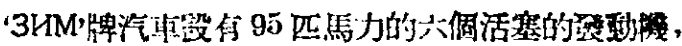

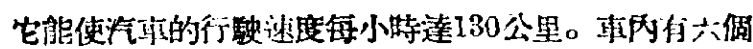

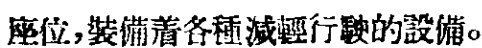

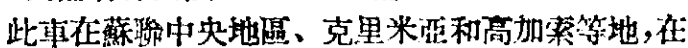

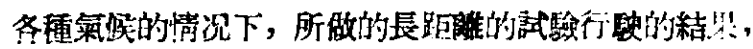

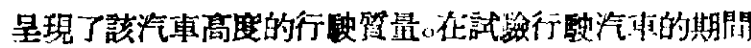

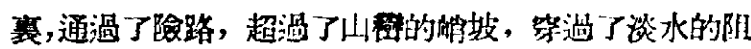

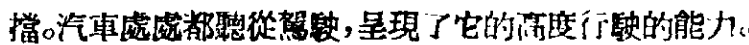

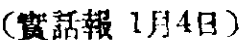




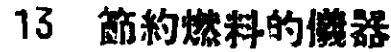

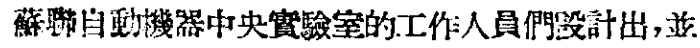

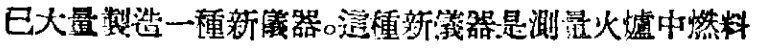
的二氧化炭和氧的數湿用的。

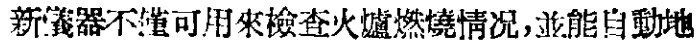
調節燃料的燃燒過程。新㼁昆運用到工棠上時，能以保 㫌更加合理地使用燃料。

（實話報 1月4日）

\section{4 水下切截金屬}

近邞年來，蘇聯的水下切截金儌的技街非常發展。 已用雷氧設備代替了星氧吹管。

现在,河止打拱破損船隻總管理局的潛水夫在水下 又探用了切截金雷的新式体氧吹管。

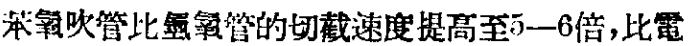
氧切擮的速度提高至3一4倍。

切截厚澾十公厘的金第板的速度，每小恃是 30 弪 人。苯氧吹管的火熘甚至能呀透厚至 80 公厘以上的甲

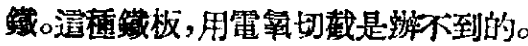

(惯話報 1月4日)

\section{5 新式火柴}

蘇聯火柴工業的中央科學呼究實騟室, 刻正從事研 究各種能在一切場合一一不受氮绝、温度、風和水的限 制一一使用的新式火柴。

科學工作渚澾尼洛夫同志研究出一種新式火柴。這

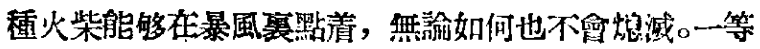
科照工作者默洛柯夫同志研究出一種 可以照燃多次的 新式火柴。這種火柴比普通火柴稍大一點, 但是它住着

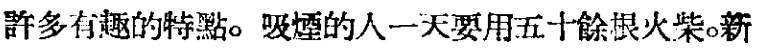
式火柴,同播的一根就能䈍燃多次。

默洛柯夫同志還研究出一穆高溫然烓的新型火柴。

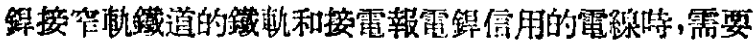
用高溫熔接洲。但是它只有在高温之下才能巶着。在以 前,就必須使用電坬才行。逼是很困難的，尤其是在離居

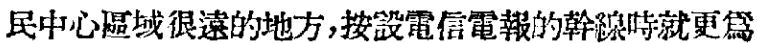

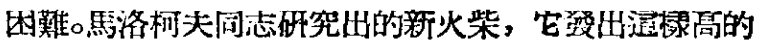

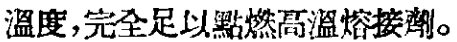

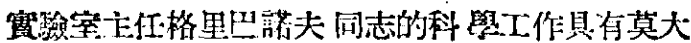

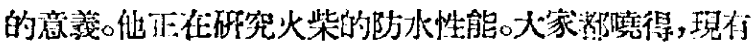
的冬種火柴非営容易受潮。格里巴諾夫同志呼究山一種

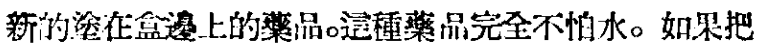

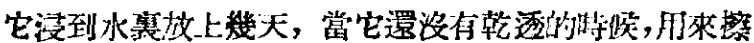
火柴一椂能着。現在正淮行第二步研究.工作:一需要研

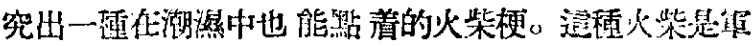

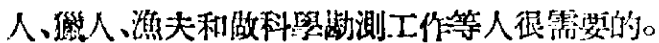

（察話報 1月4日）

\section{6 探棉機}

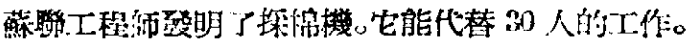

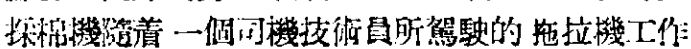

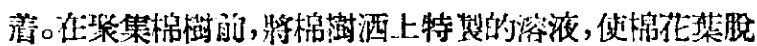

落,然後開始探棉。

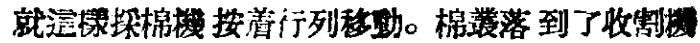
內，利用势紡縋的旋轉器將棉化從開口的盒內抽出，棉

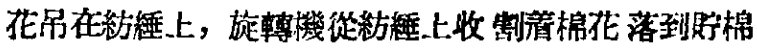

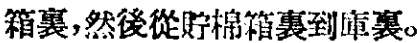

使用深棉機，疑然是減低了势動力的消耗及縮短了 收㴧期,這栐就完成了1947年聯共(布)黨中央委員會二 月會籖所嫢定的任務之一。

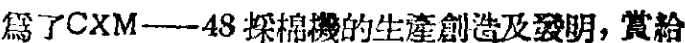
了.工程師們 $\Gamma$ ・弇耳蕳夫、几・洛金布留姆、M・馬耳

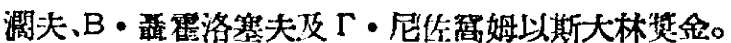

（東北中蘇反好 No.33）

\section{7 馬鈴薯康拜因}

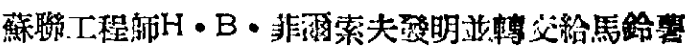

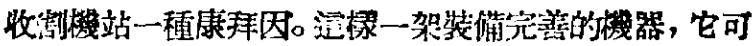

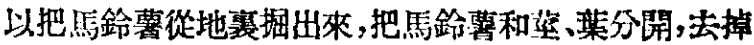

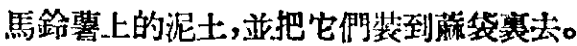

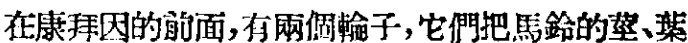
抓住，把姿、葉和球根分開，再把它汧到一旁。然後，兩倜

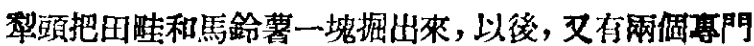

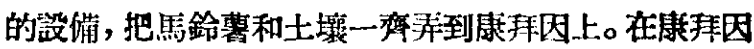

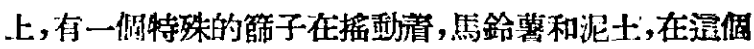
節子旁被分開，泥土漏到下面法，馬鈴薯則被留在上面。

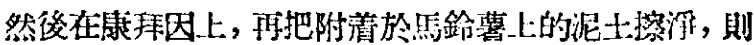

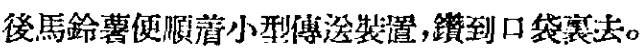

逼個機器, 可以脚在輕拖拉機上, 佂一個工作日中,

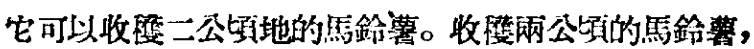
普通得需要 45 -50 人來做的工作, 而用造種康拜因, 只 有三個人便够了。（東北中蘇奴好 No.35)

\section{8 黑龍江沿岸的米邱林式公園}

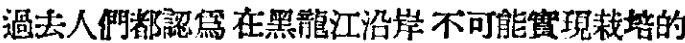

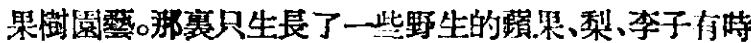

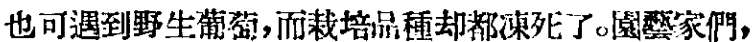

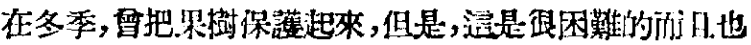
没可篚的肴孯。

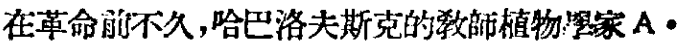

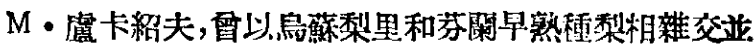

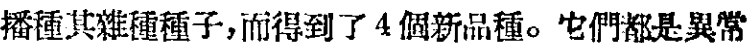

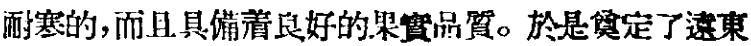
栽培果樹阅藝的基礎。

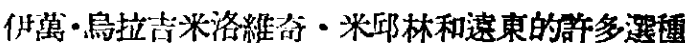

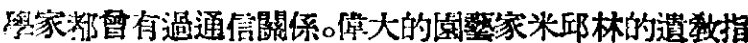
鹗了他遠東繼承者們的事業。在哈巴洛夫斯克舉開的果

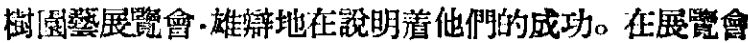
上陳列着許多大寸的青年米邱林學者所提出的展䁷品。

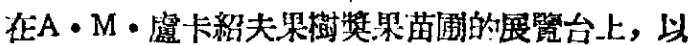

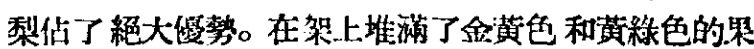

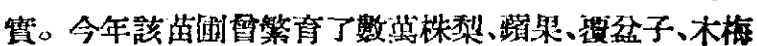

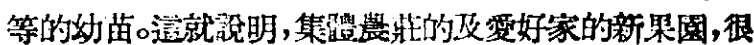

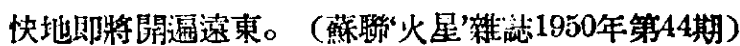

$$
\text { 第二期科學 通報 }
$$




\section{9 保聯歐洲部分草原地带正在 菑現造柊計割}

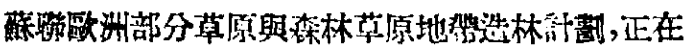

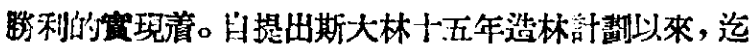

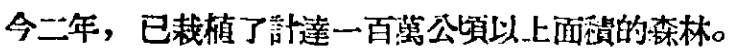

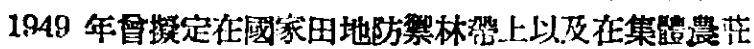

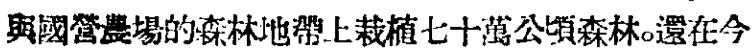

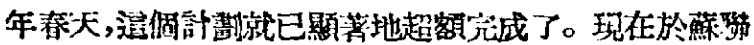

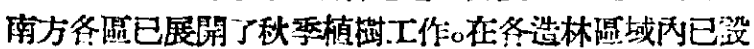

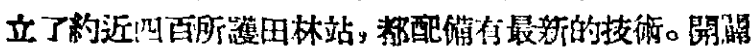
备造林陣的一切工作都月機器進行。

（果北费業 No.21）

\section{0 冬小麥的新品程}

平彼得洛夫斯克国家選種站育成了量高而 不倒伏的冬小娄新品種“彼得洛夫斯卡雅”'。造一品種是

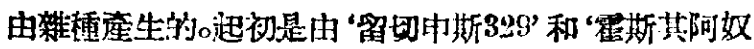

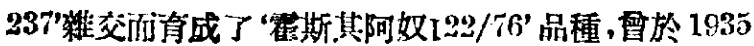

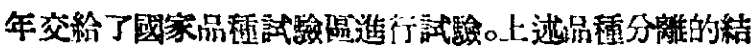
果, 䎦兩次選拔後, 育成了無革品系, 塄就是“彼得洛夫

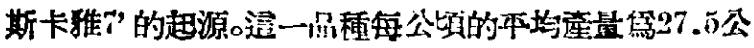

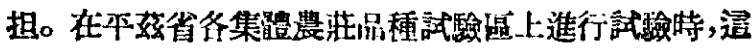

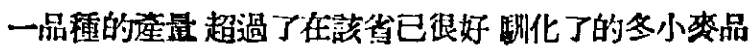
種一一“埃里洛培姆46/,131'纹“烏里揚諾夫卡”。

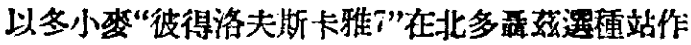

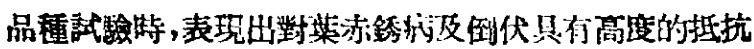

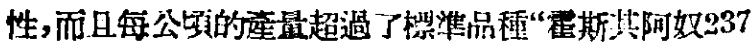
”。.05公担。在哈利克夫選㣫站試验特，其量也超過了

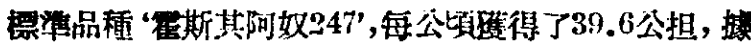
哈利克夫選種站的觀察，新品種表現了充分的抗寒性和

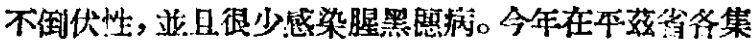

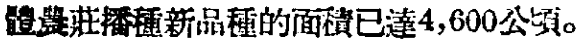

（“集體農茫生產' 1950年第8期）

\section{1 抗潘性裸茤}

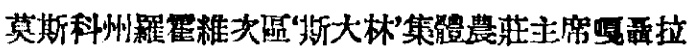

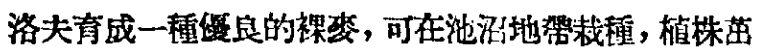
壮, 麥傕豐洋。

(Огонек (火星) No.33 Август1948)

\section{2 玉采的春化}

我們知道, 玉米的倜题發有㴧程, 普通是要求高溫 的, 而關於玉米的春化問題, 证如李森科院:士指出的一 直至現在却研究的很少。我們筧以雨㑬試驗小愠，一

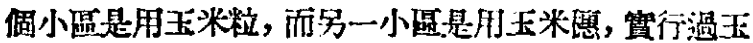

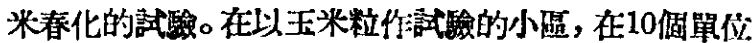
重的㮔子中以3個單位雷的水，使㣫子洆潤。這一工工作 是在 $15 \sim 15^{\circ} \mathrm{C}$ 的條件下，穞兩萣夜分三次施行。然後将

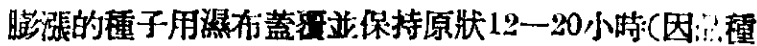

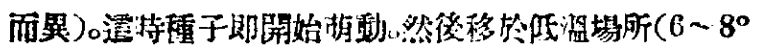

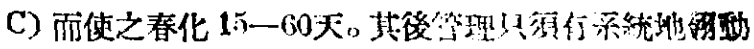
種子和調解其水分国浿度即可。

第二小區是選取一些玉米瑟，把它們漫於 $15-18 \mathrm{C}$

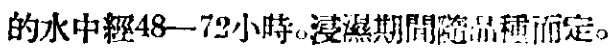

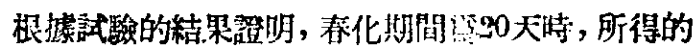

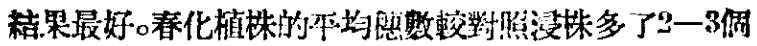

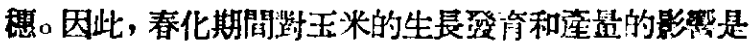

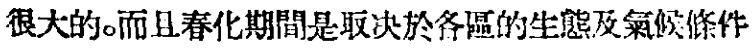

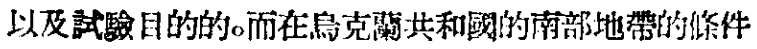
下以春化期間15-20天时的縚湾效果最大。

一波洞强克一（'自然〔Природа]1950年第8期)

\section{3 無性的蒖果}

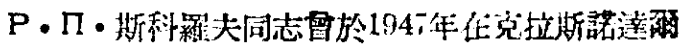

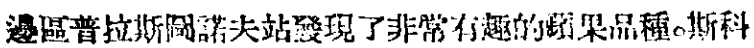

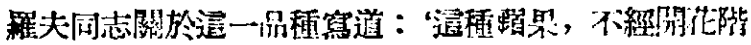

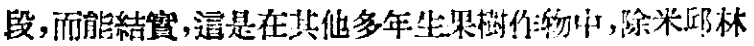
在1932年所記述的梨以外，是看不到湾玨现象的'。

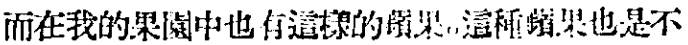

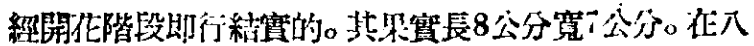

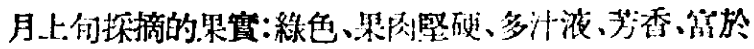

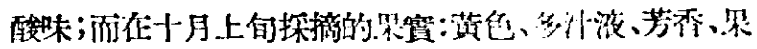

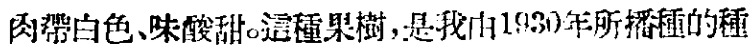

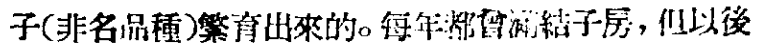

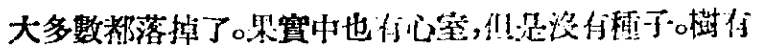
抵抗性, 冬季末施任何蓝要。由這一频果樹, 已得到了兩 棵幼樹,它們也是不程開花階段的結望的。

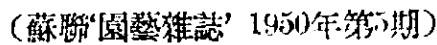

\section{4 合成的動情素}

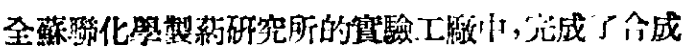
的動情素(Oestrogens) diethylstibestrol浓 diethylsibb

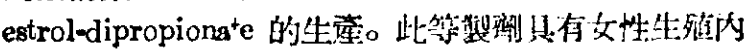
分泌素Oestradiol 的全部性能, 们與它不同的地方, 就

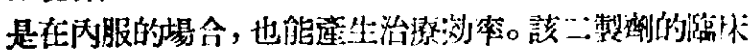

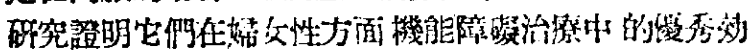

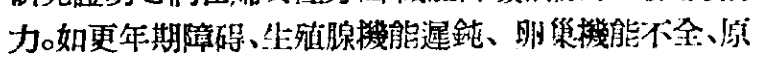

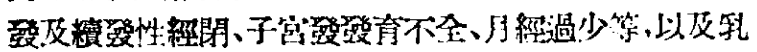

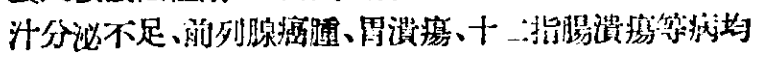
可治潦。

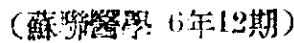

\section{5 葆聯科學院近訊}

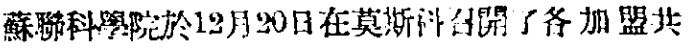

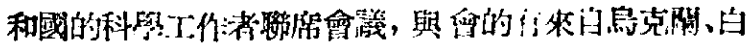

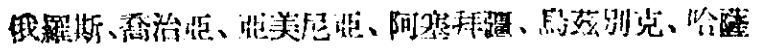

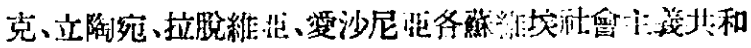
國科毁院的代表。

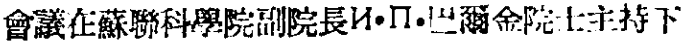

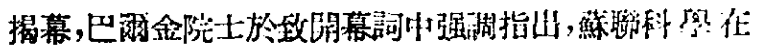

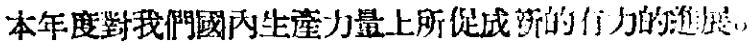

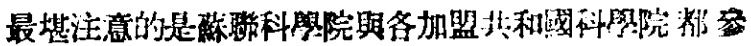


加了隐大的共座主義建設的领造 L作，一一水電站，渾 河與新灌啭系統的湕設工作。

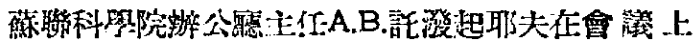

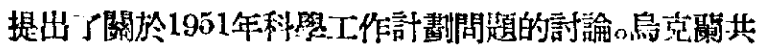

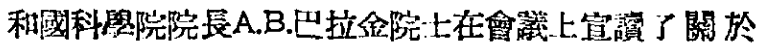

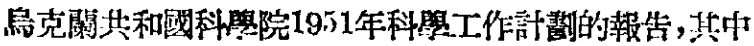
包括了來年研究中心107項科學上的問題。

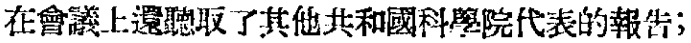

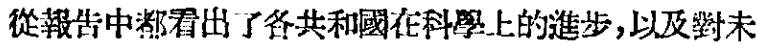
来的研究:工作所樹立了的更明確的違景。

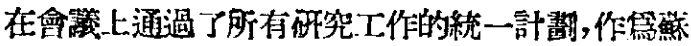
聯科祭院及条加盟共和國科祭院今後在研究工作，上：進 行的指南。與會的科翼家一一冬加盟共和戴科學院的代 表都表示了熱烈的愿空，要櫴結自己的力量立結合到徨

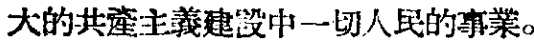

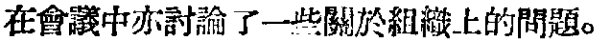

會議於十二月中二日宣告閉慕。

（是理報 1950.12.21. 社會農業報 $19 \% 0.12 .23$.

\section{6 萑聯科學院會議討論1951年 工作計割}

在莫斯科,冬盟具共和國科學院科學活動调整委是

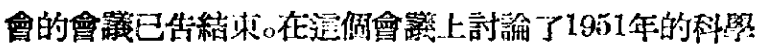

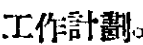

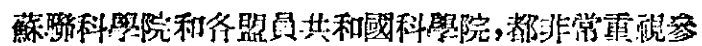

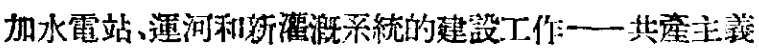
僚大建築工程。

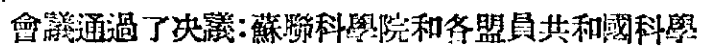

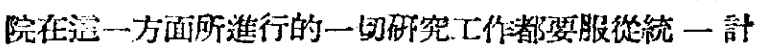
劃。备盟員共和國的代表一一學者們都熱烈地表示, 源

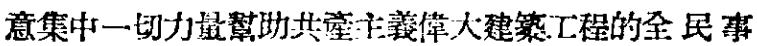
業。

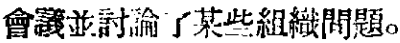

（害話報 1月10日）

\section{7 蘇聯科學院舉行十二月黨人 起事125㥜年紀念會}

科照界知名人士熟烈夢祝十二月黨人起事 125 遇年 和念。1950年12月26日在莫斯科和列窂格勒召開了蘇聯 科䍙院歴史哲學部與交學珸言部的聯合集會。

在莫斯科石開的集會上, 蕉眑科的院副院長B.П.伏

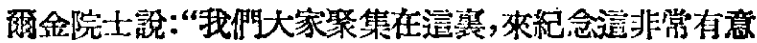
拿的日子一十二月黨人起事125崌年紀念日。十二月黨

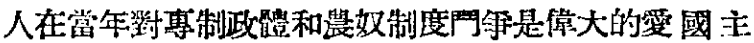

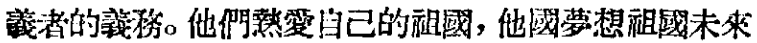
的光耀 ......"

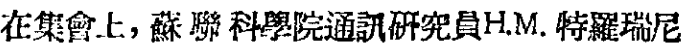

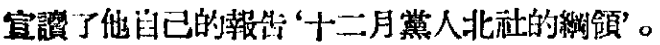

在列察格勒的集會由 5.0 . 葛立柯夫院士主持䑁行。 在他的演筒神中，强調“了十二月黨人起事在俄國革命運動

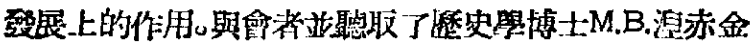

諾传和A.B.發列特間青斯基的萳出。

$$
\text { (车理郝 1950.12.27.) }
$$

\section{8 蘇聯生物學拍的科學含議}

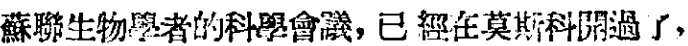

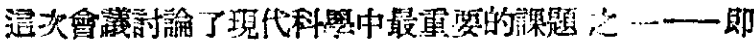

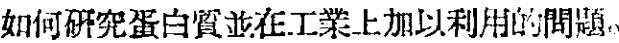

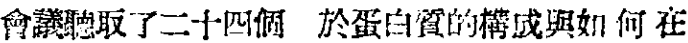

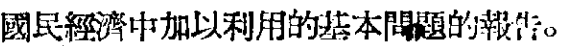

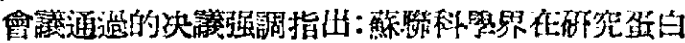

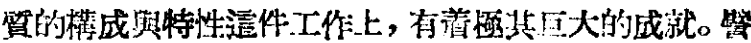

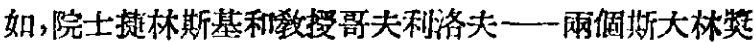

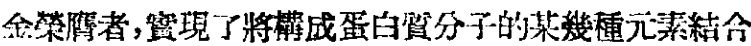
起來的目的。還有其他蘇眑學者所進行了的很多需樑的

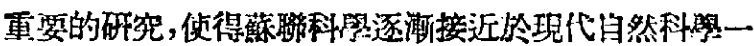
個根本問题的解决一合成蛋白資。

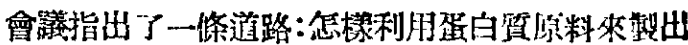

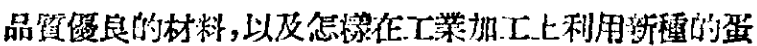
白留原料。

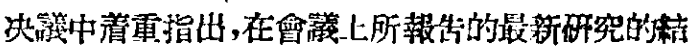

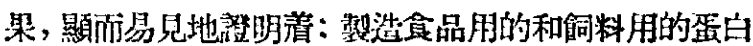

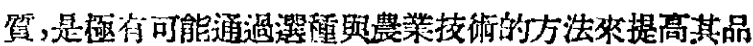
管與數揘的。目解已研究出多種方法能在公共食堂的食 品中、食品工莱中和收育業中合理地利用蛋白貿，並把 幾璉蛋白筫合理地配合起來。（實話袁 1 月7日）

\section{9 蘇聯科學院舉行電子影散鏡 會議}

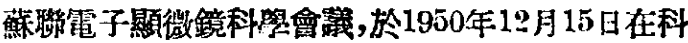

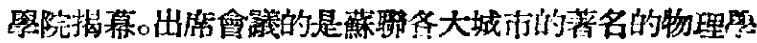

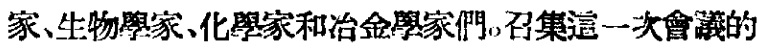

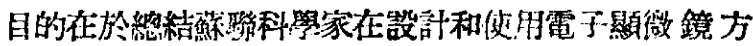
面的成就。蘇聯落名物理學家、科量院院:上雷必得夫政

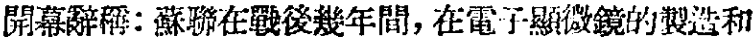
隹泛使用於冬科壆和技術部門方面，都㨦得了重大的成

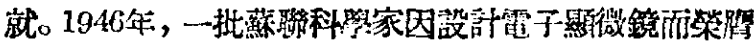
了斯大林奖金。

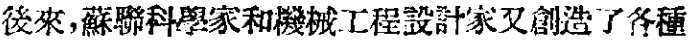

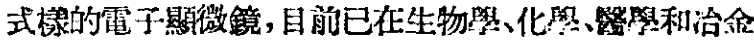

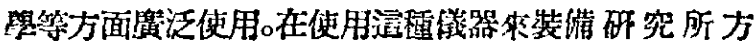
面, 蘇聯現已佔比界的首位。

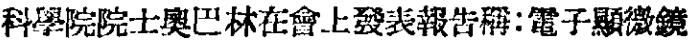

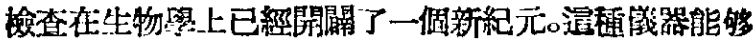

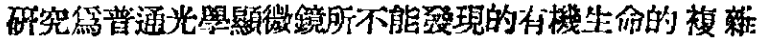

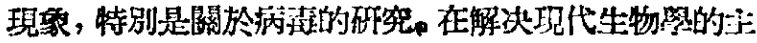

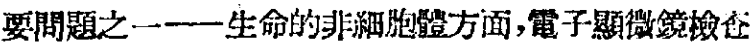
也担負了鼠重要的任務。

(新藏流楬 1950.12 .20$. )

\section{0 蘇聯郵军怔明與合理化建議 審查大暨}

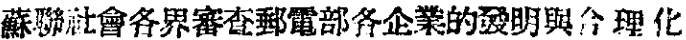

$$
\text { 第二期 }
$$




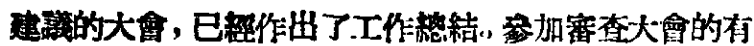

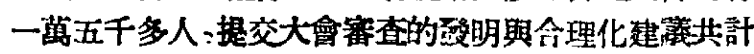
二萬二千件，其中有一萬四千件已在生座中加以探用。

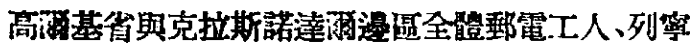
格勒無䠌電廣播管理處全管人員與基輔郵局全體人員 都得到了一等獎金。（曾話報 1950.12 .30$. ）

\section{1 切霜諾夫逝世三十週年紀 念}

俄國冾金祭者切爾諾夫在卓越的俄羅斯科學研究 家之中，佔居着默著的地位。1月9日，當切爾諾夫逝扑三

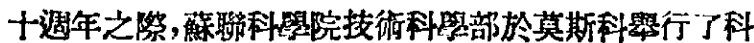

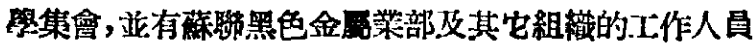
加。

（筫話冁 1月11日）

\section{2 蘇帏科學界鹿祝箸名漢學家 亞列克塞耶夫七十誕辰}

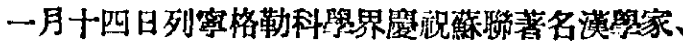

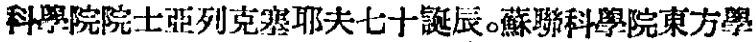

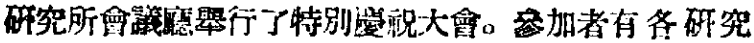

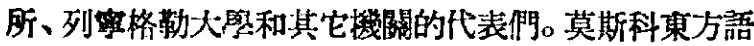

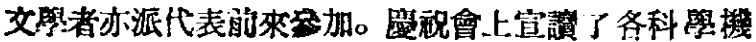
關、各高等祭校和個别科㩆家們的無數封賀雨。

留列克塞耶夫院士畢業於彼得堡大照，是最著名的 的國漠等家們的學生。四十多年前，他在彼得堡大學開 始了講師和数授的生涯。他曾到中國族行過三次，大量

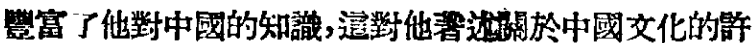
多著作踪助很大。亞列克塞耶夫的著作對伐國關於漢學 方面的研究有很多貢㱆。在最近幾年間, 亞列克空耶夫 在非常歎染的中國交字中作了很多的研究，立獎它們翻

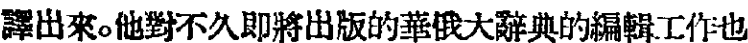

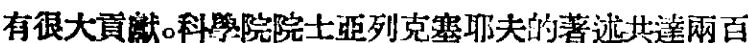
多種。

（新華椡稿 1月19日）

\section{3 科學家與集鳞莊貣間創造性 的合作}

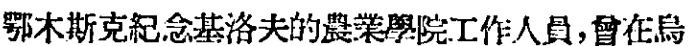

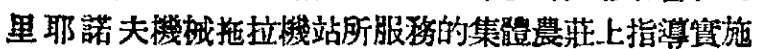

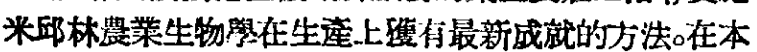
年度該農業學院的科照工作者更協助集體農莊改行牧 草制度，大部分的集體勞作從事於播㣫、牧草和造林，更

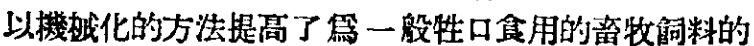
獬備。

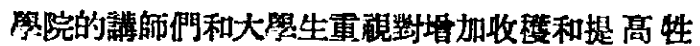
口生座的新的方法的有效宣傅。在一年之中曾在集體農 菲作了將近阿百次的演講, 更由熟鍊的專家們主持舉行 了筷多次的座跀會。

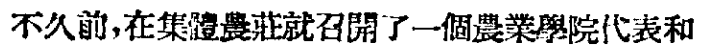

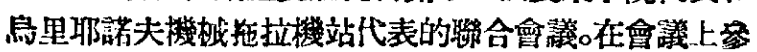

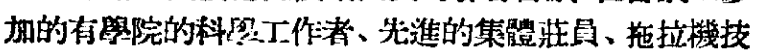

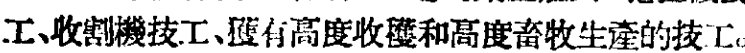
他們總綃了一下他們一年來所創造的成就，前計劃明年

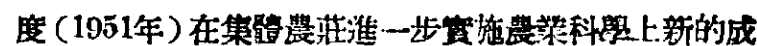
就的途狏。

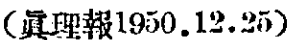

\section{4 蘇聯蓄名科學家貝丽格逝世}

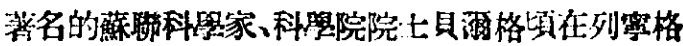

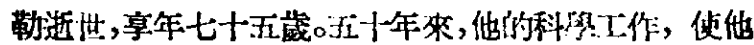

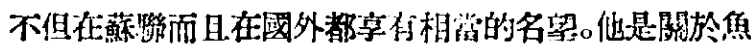

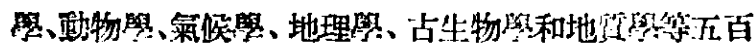

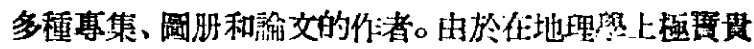

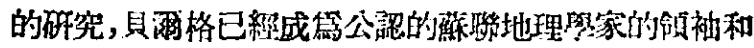

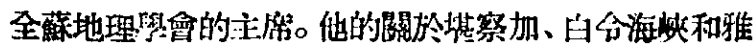

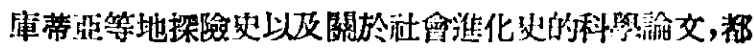

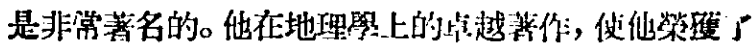

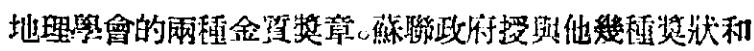

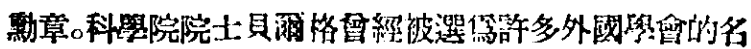
譽會員。

(新華社稿 1月6日)

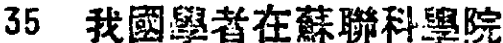

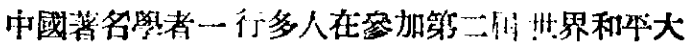
會後,來到莫斯科,並於十二月九日訪問集聯科量院。蘚

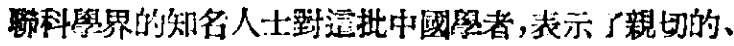
支誼的鹳迎。

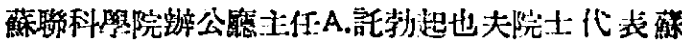

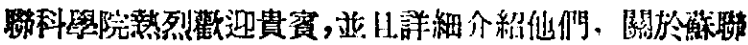

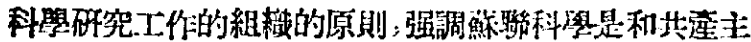

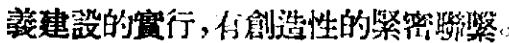

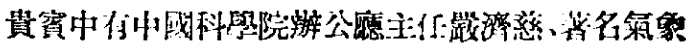

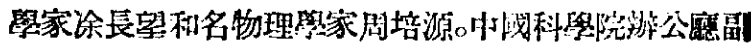

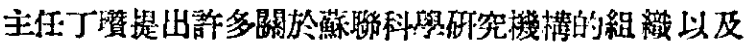

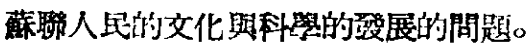

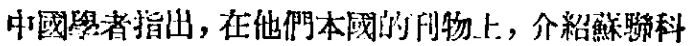

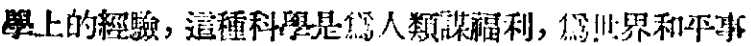

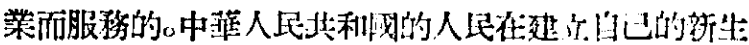

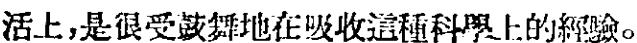

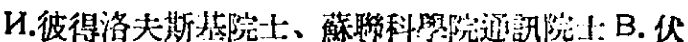

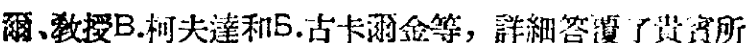

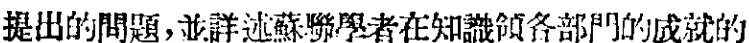

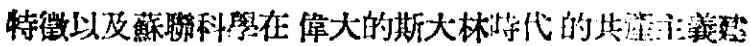
設中的作拥。

(氛理報 1950.12.10.)

\section{6 薜聯科學院頒發1950年獎金 與獎章}

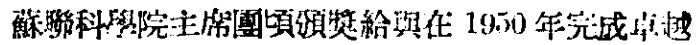

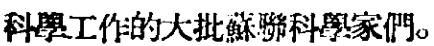

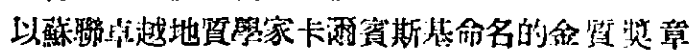

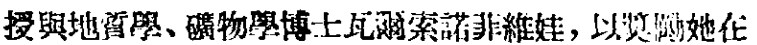

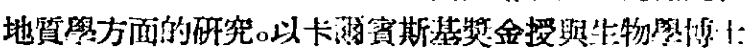

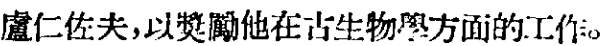

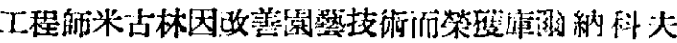

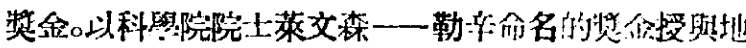

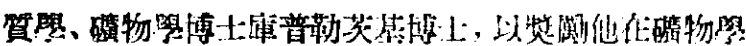




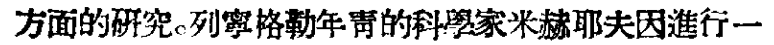
系列的關於結晶祭的研究，策獲列多羅夫獎金。

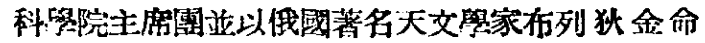

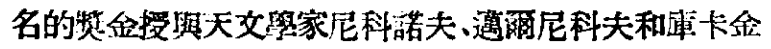
三人。科學醉究工作的人，科期院院士咸巴林、米丁、通

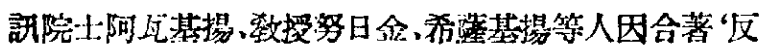

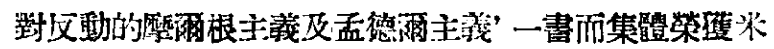
洂尼科夫篹金。

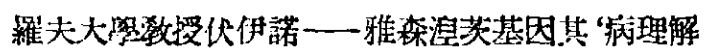

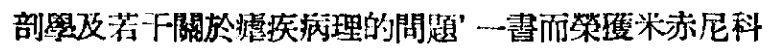

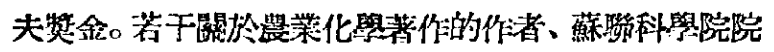
士波諾䲱列娃及羅查諾夫所領尊的土壤研究所中的科

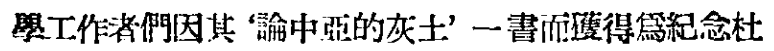

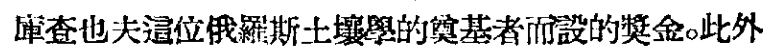

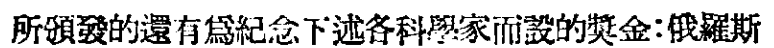

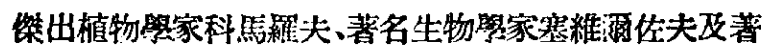
名物理學家曼德瀜斯坦等人。

$$
\text { (新華社稿 } 1950.12 .26-27 .)
$$

\section{7 蘇聯取高蘇維埃主席團聘請 各國代表組成 ‘加强國際和 平' 斯大林國際獎金委員會}

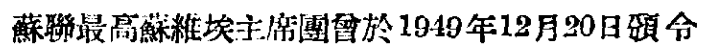
設立了“加强國際和平”斯大林國際桨金。

根榩此項指令, “加强國際和平” 斯大林國際獎金每

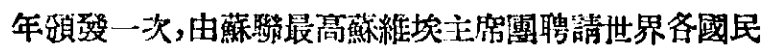
主力量的代表組成之斯大林战際獎金委員會領登之。

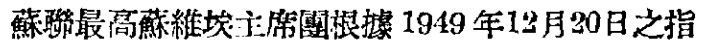
合於 1950年12月92日組成了“加强國際和平”斯大林國

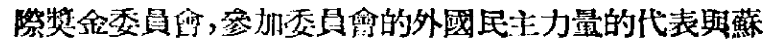

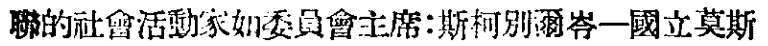

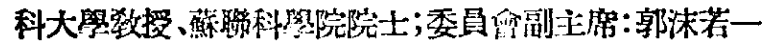
数授，中國科的院院長、中菲全國文學與藝街工作者協

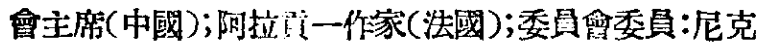

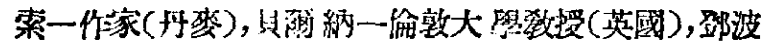

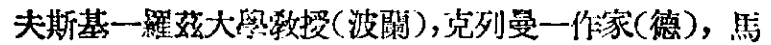

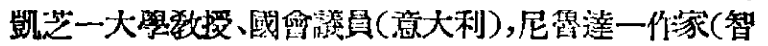

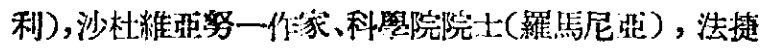

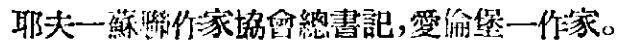

（實話報 1950.12 .30$. )

\section{8 巴甫洛夫全集第二版已 出版}

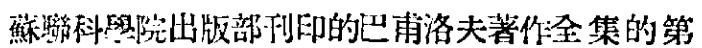

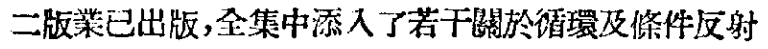

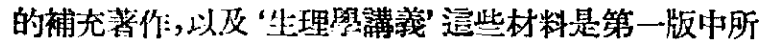
沒有的。書中關於各指定的問題，都按照每種著作的年 代次序㖇分別, 此項全集包括六卷(八册)。此外另有附

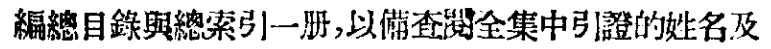
其中著作的索引。坿編中同時也要登截巴甫洛夫一生的

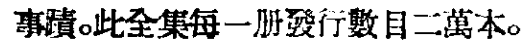

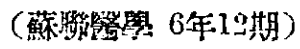

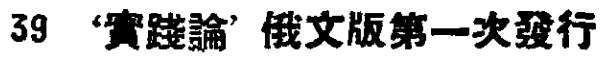 五萬册}

毛主席的著作“筫践論”已由薢徏國 立政治 视物出 版局印成俄交單行本問世，譯者褊费多林科，單行本第 一穴印行五䔽册。

（新型社 1月13日）

\section{0 羅馬尼亞今年開工興建列察 水力發電站}

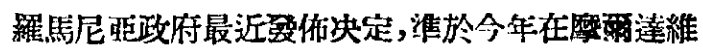

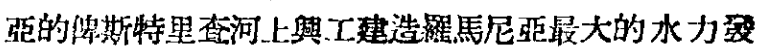

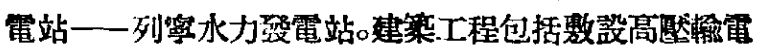
綫和修建焹電所等。在電站附近並將興建一座容量達十 二意立方公尺的䈉水庫及其他水利工程。到1957年全部 .工程完工後, 電力站墢電力將達二十一萬艇, 全年發電

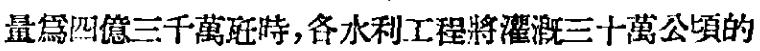

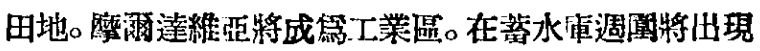
許多電氣化的新城市和㖘菣。

\section{(新華满上稿 1950.12 .29$. )}

\section{1 保加利亞人民的新建築工程}

國務院和保加利亞共座黨中央委買會通過了關於

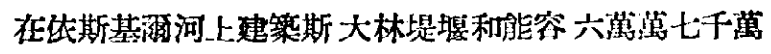
立方公尺水的貯水池、修筑三個發電量第泣、萬七千多基

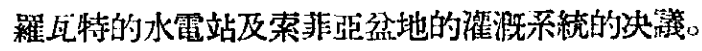

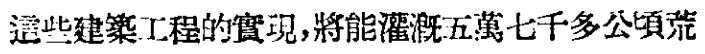

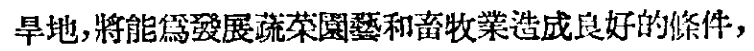

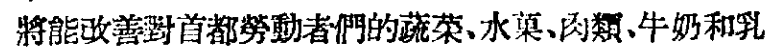
彆品的供㯺。

堤堰和水電站的建築，亦將能充分保澄菜菲丝的工 業和居民以及隣近許多城市的䉓力和食用水的需要。

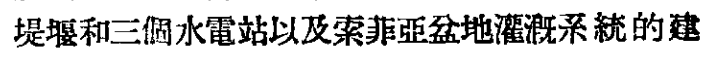
筑,將在1955年結束。

(實話報 1月11日)

\section{2 波蘭的化學工業}

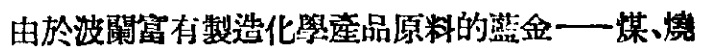

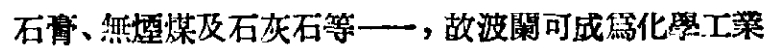
極登達的國家。

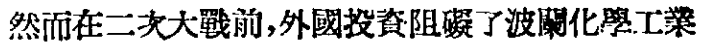
的發展，當時外國投㗄筧佔全部化工業資金的60-87\%

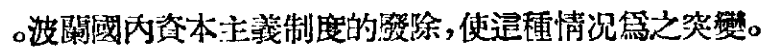

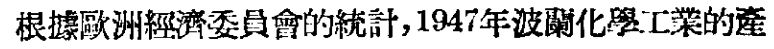

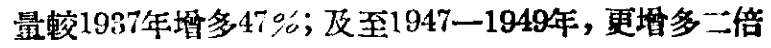
住餘。1938年它佔全歐裳量的 $4.1 \%, 1949$ 年歌洲的化.工

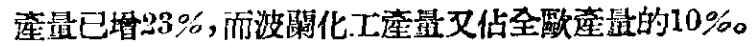

1949年波闌主要化卤物品之在量有如下表：

\begin{tabular}{|c|c|}
\hline 人造肥料 & 199,000 收 \\
\hline 氮肥料 & 166,000 㳩頁 \\
\hline 确酸臨 & 126,000 澒 \\
\hline 染 料 & 3,700 瀬 \\
\hline
\end{tabular}

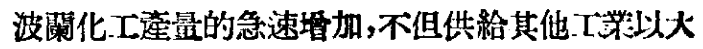
量的化罧物品, 亚給農業方面更多的人造肥料。例如

第二期

科學通埌

- 207 • 
1949年每哈 (ha) 所用的肥料较1938年要多140\%。同時

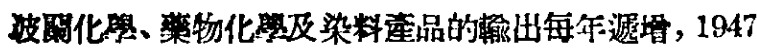

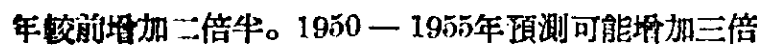
4:之多。

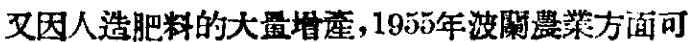
䜿得较 1949年多三倍，比践前多七倍的人造肥料。此外

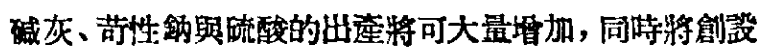
慜造有榙合成物的基礎，並開始製造人造物品、合成燃

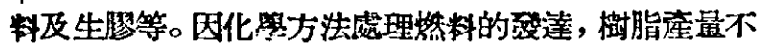
但管多，並可由补煤中提出。

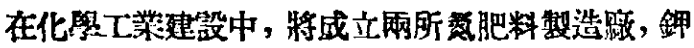

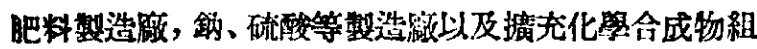

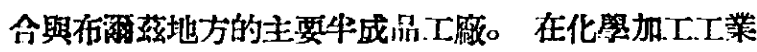

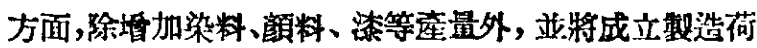
孀蒙合成物與維他命的新機構。

1955年波闌化學工業主要物品有如下表：

\begin{tabular}{|c|c|}
\hline 硫酸 $(100 \%)$ & 540,000 顿 \\
\hline 喊灰 & 389,000 噸 \\
\hline 法性䣄 & 162,000 活 \\
\hline 㑹肥料 & 230,800 煩 \\
\hline 瞵肥料 & 250,000 㖽 \\
\hline 銤肥料 & 16,000 櫴 \\
\hline 殺虫诫 & 26,900 噸 \\
\hline 染粘 & $7,900 \mathrm{~A}$ \\
\hline 裸電極 & 31,000 \\
\hline 合成生噖 & 13,000 \\
\hline 林 & 八千境等 \\
\hline
\end{tabular}

('Polish Bulletin' No.21)

\section{3 波萿梨糖業}

波閶是歐洲最早整糖國家之一,19世紀的四十年代

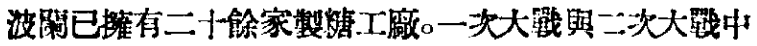

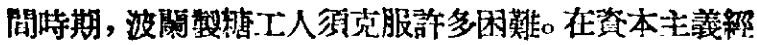

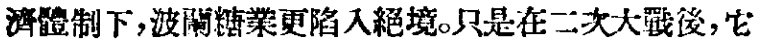

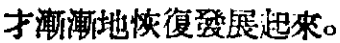

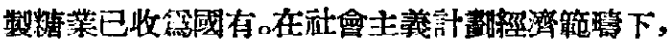

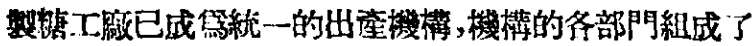

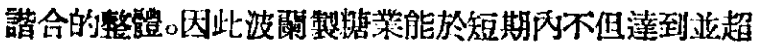

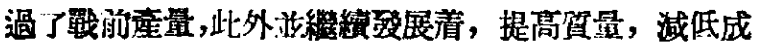
品。

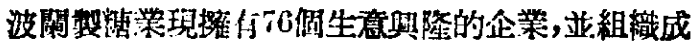

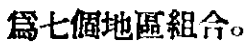

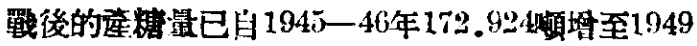
一50年的760,000頉。1950-51特可增至 830.000 獺。

('Polish Bulletin' No.:21)

\section{4 保美溫青路的新方法}

由於碎石的新處理，英國科學家已試鮯成功焦防止

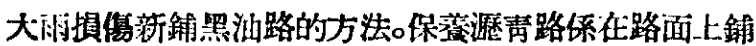

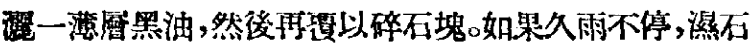

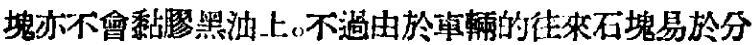

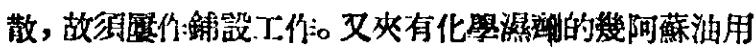

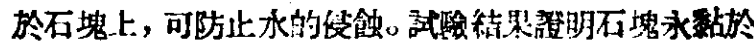
路面一。

(Sicience News Letter' 19;0.10.14.)

\section{5 保加利亞费業的新氣壆}

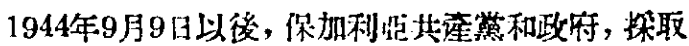

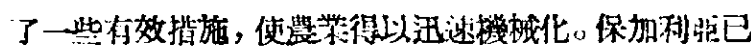

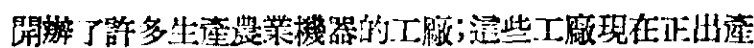
青打款機、播種機、制麥機、拖拉機的零件，以及其能各

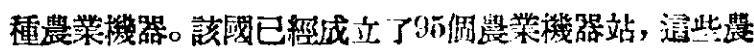

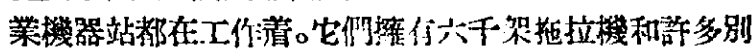

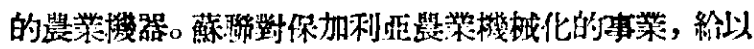

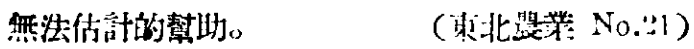

\section{6 匈牙利的土質改百工作}

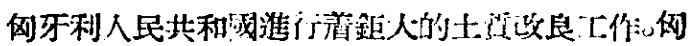

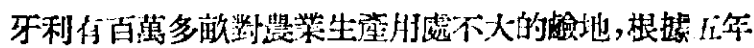

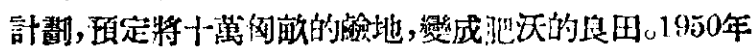

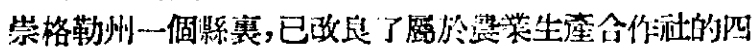

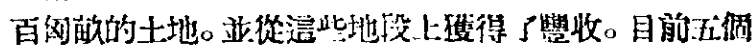

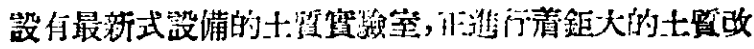
良研究工作。

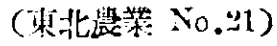

\section{7 北美洲發現安前期恐啨}

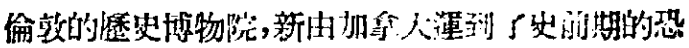

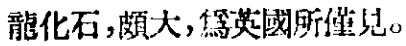

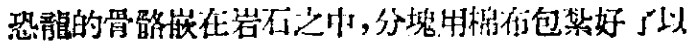

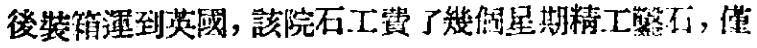

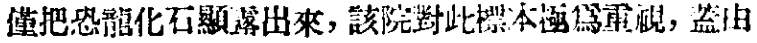

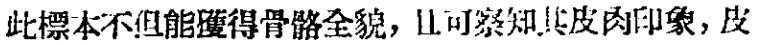

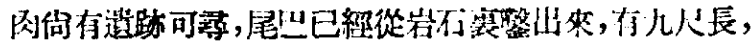

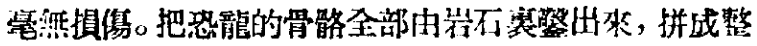

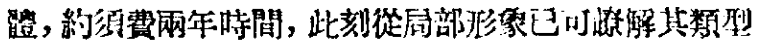

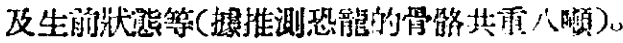

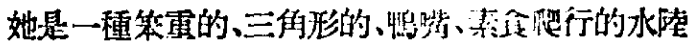
兩椋趵物。

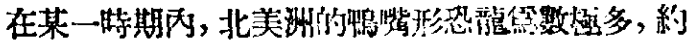

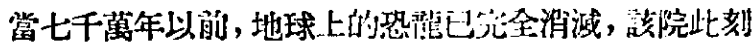

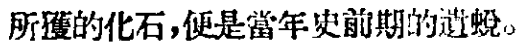

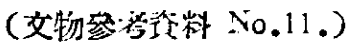

\section{8 在瑞士山頂進行宇宙線研究}

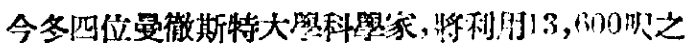

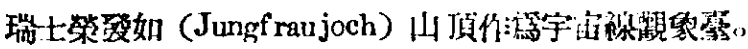

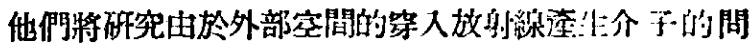
題。

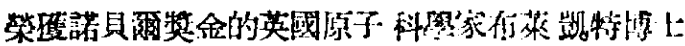

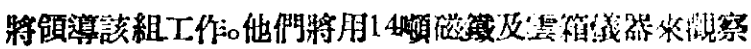

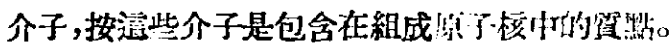

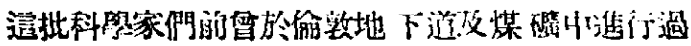
宇宙踩的探测。

('Science News Leiter'195i.i).7.) 


\section{9 特殊設計的雷達}

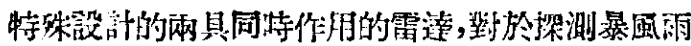

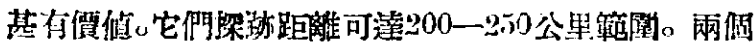
需澾器：一润䋆裝置在美國新傑西州的蒙帽司港, 另一 具毁於跬省的㓣橋地方。

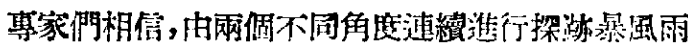

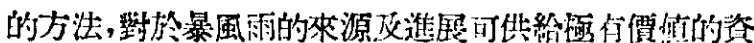

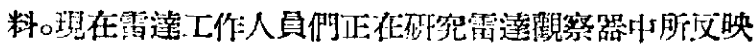
出天突中部分的景象。

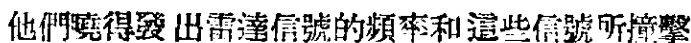

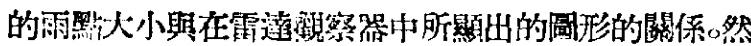
而他們何不能精確知道在雷澾信號湖未徒這些雨默折

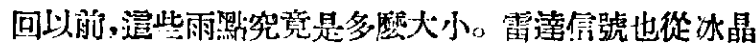
反射折问，所以同様的問題也存在着。所有邆些以及其

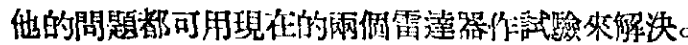

('Science News Letier' 1950. 10.7.)

\section{0 㹂波測量水速度}

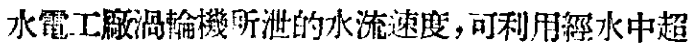

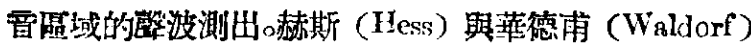

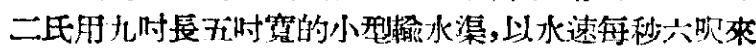

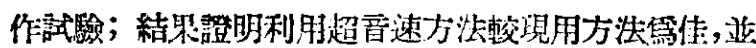

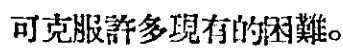

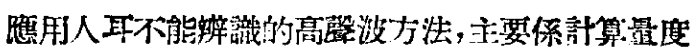

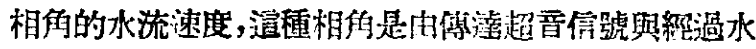

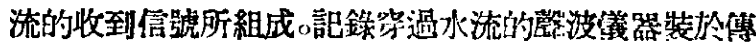
達器對方的水渠壁上, 证沿主裂流軹移置一定距離, 以

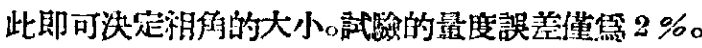

('Science News Iueiter' 1950.10.14.)

\section{1 熔化鵭時所座生的電子熘}

G. E. 研究所 J. D. Cobime 氏對陮用超高周波

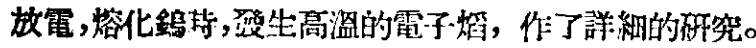
由磁電管嬁生周波数的 $109 \mathrm{C}$ 强切的 Micron 波,導入

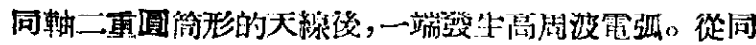

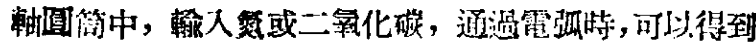

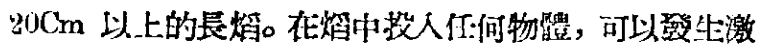

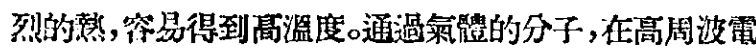

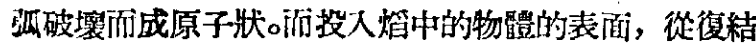
合成分于時,亦將酸生高熱。所以焰本身不一定有很高 的溫度。

('Science News Leiter' 1949.11.19.)

\section{2 用鋁代替高速鋼內的鵭}

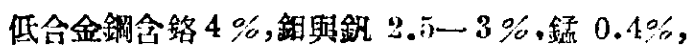

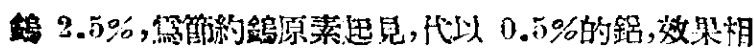
等。無論鋼內有無鋁,其淬火溫度相同，但含鋁鋼須经 $560^{\circ} \mathrm{C}$ 溫度下回火二文，每次3分鉝，以得到!一足硬度。

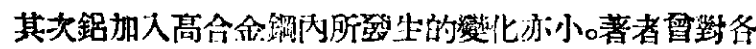

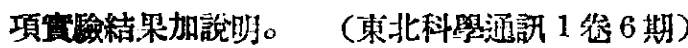

\section{3 鋁的精製法}

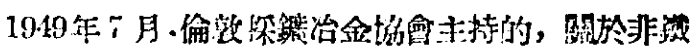

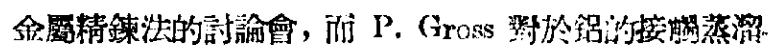

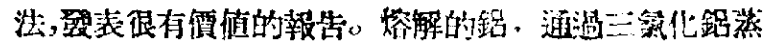

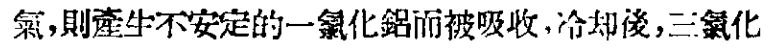

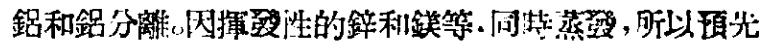

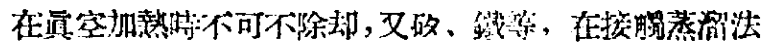

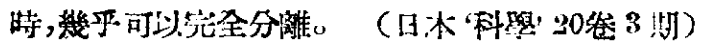

\section{4 重金屬合金}

英國 Wembley 的 (i. E. 公司研究所, 最近進

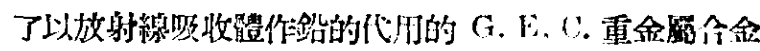

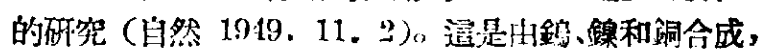

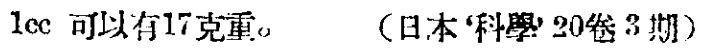

\section{5 第五族元素的結晶化學}

洨加琴大照 W. H. Znchariasen 氏從 Ac (80號元 素)到 $A m$ (95栫元素)元素的化命物，作 290 餘種的絬 晶解析，證惯了 Niels Bohr 的頓零 “類似第四族 (4f) 元素(稀士類元素)的第五族 (5f) 元素列開始”。就是在

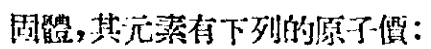

\begin{tabular}{|c|c|c|c|c|c|c|}
\hline \multirow[t]{5}{*}{$A c$} & $\mathbf{T h}$ & $\mathrm{Da}$ & V & $\mathrm{NP}$ & $P_{11}$ & Am \\
\hline & & & $\mathbf{3}$ & 3 & 3 & 3 \\
\hline & 4 & 4 & 4 & 4 & 4 & 4 \\
\hline & & 5 & 5 & & & \\
\hline & & & 6 & 6 & $f$ & \\
\hline
\end{tabular}

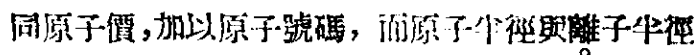

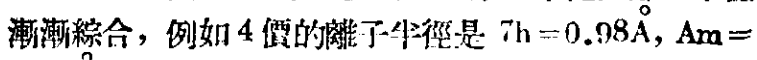
$0.88 \AA$, 如收縮, 於 $5 \mathrm{f}$ 款小收入電子是不问能。旦與 $5 f$

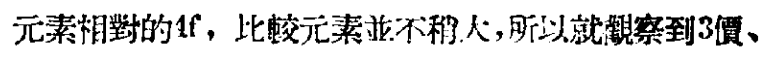

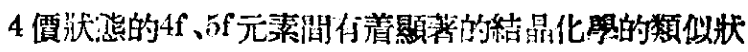
態。

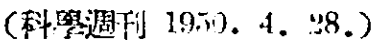

\section{6 锌之地球化學的分布與化學 組成物}

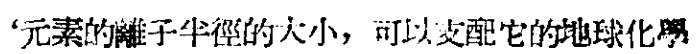
t.的分初”，通是 V. M. Goldschmidt 行提的原理。

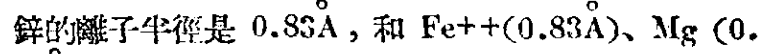

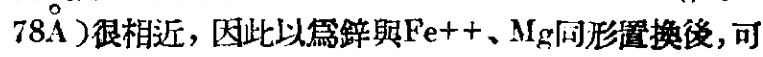

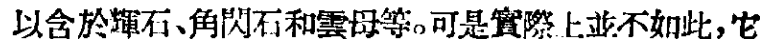

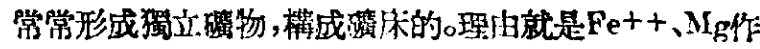

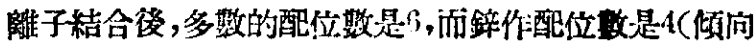
四于洦體方面)的等極結合的傾向很强, 所以兩者要琵 换是很困難。鋅㯰換配位数 4 的元素, 例如 $\mathrm{Hg}$ 踓然

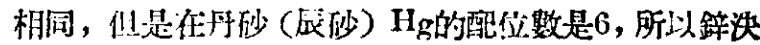
不能加人.黑丹砂是4，而鋅近於5\%，因此便可琶換了。

元素的分析，是由化學組成的性筫所支配着的，通

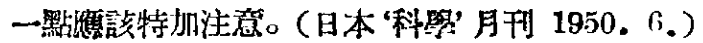

\section{7 用于電子影敞鏡的標本}

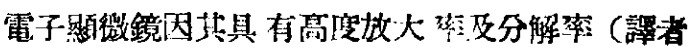

第二期科學樋報 
按：現英國出品之電子㙷微鏡如 Metropolita-n Vickers Electrical Co. 所造者, 其放大率第 $100,000 \mathrm{X}$,分解能

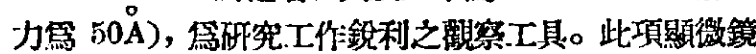

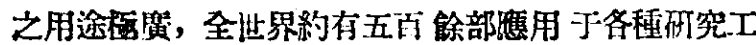

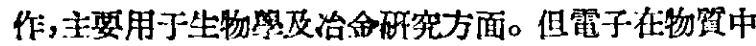

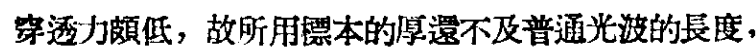

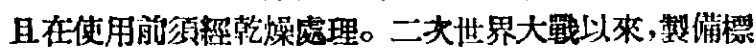

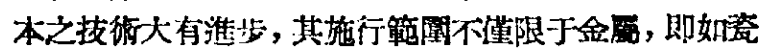

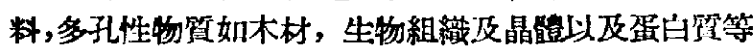
亦可製成切片。生物切片的悬度可切至 $0.1-0.2$ 埃米 $\left(10^{-4} \mathrm{~cm}\right)$ 。

('Nature' 165: 1009)

\section{8 瑞典地質學界近况}

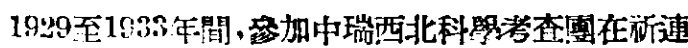

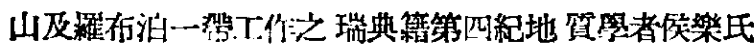
(Dr. Nils (i. Häruer) 以心䑏病不治, 於1950年11月21 日病逝於瑞典额潽赛拉。

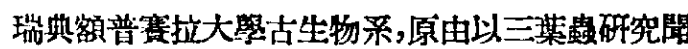
名之瑞典女古生物悬者瓦爾博氏 (Dr. Elsa Warburg) 主持，瓦氏年近古稀，自1950年春季始，系務政由原在皇 家域物院地筫部任主任之圖斯俞氏 (Prof.Per Thois lund)接手，圆氏以研究下古生代地層著名。

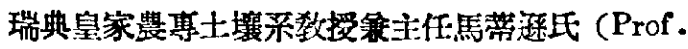
S. Mattson)将於1951年夏退休, 退休洚將往瑞典西海

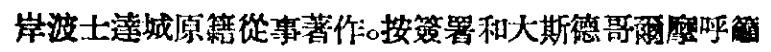
之瑞典教授共兩人、馬氏第其中之一，另一已被泊撒回

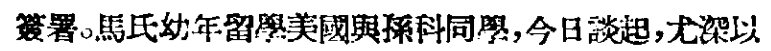

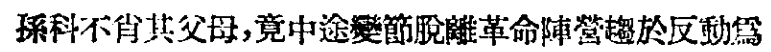

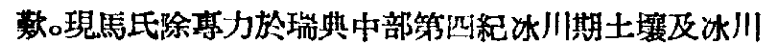

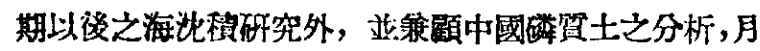

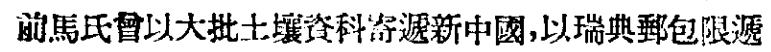
台珢,悉遭退回。

璀典額普等拉大學地理䒺数授尤斯德 (Prof.F.

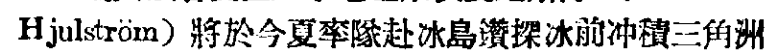
(Outwash delia)。

(陳光洜)

\section{9 芬蘭地筫學界近况}

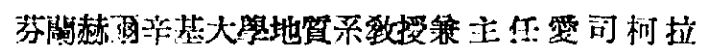

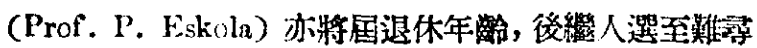

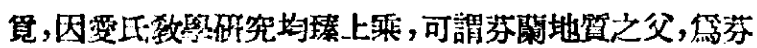
閶地望界拉较由來已久。

19.49年夏，芬閶與瑞典地贺界有交換旅行雨組，第 四紀地賀組浔断康地半岛北部芬宿境內之拉布 郎地區 (Lapland)，岩嘫組看芬闌酒南部解寒武紀及瑞典中北

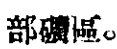

(陳光遈)

\section{0 丹麥地質學界近况}

州麥哥本哈根地啠博物舘與大學地算系两位，一體，

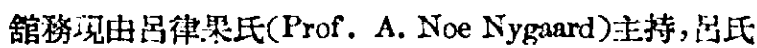
以砸究冰島泫武岩及格陵闌島前寒武紀著名。另羅生克 郎斯数授 (Prof. A. Rosenkraniz) 則爱致力於陆麥本
部及格陵簨島中生代。

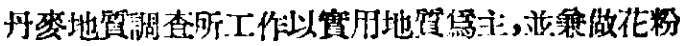

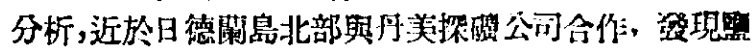

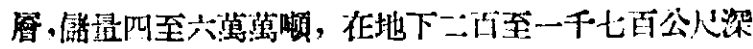

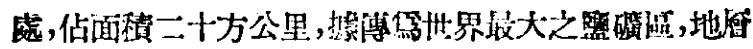

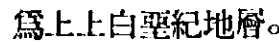

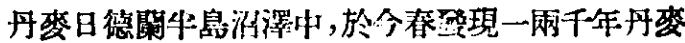

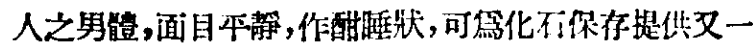
例證。

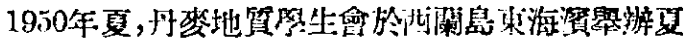

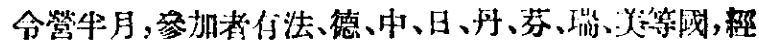

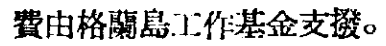

（陳光逶）

\section{1 格陵蘭岛之第鉛碳}

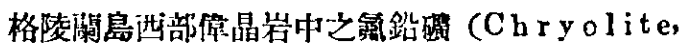

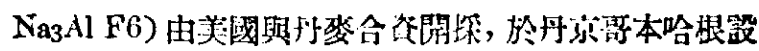

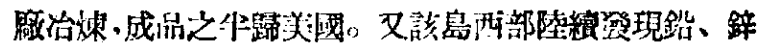
等, 份待铎勘。

（陳光橾）

\section{2 印度地震觀測龺}

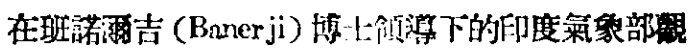

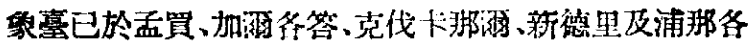
地垤立裝備有 M:Ine-Shaw, Omori-Ewing 與 Wood-

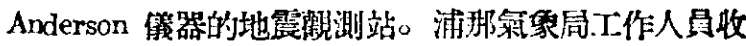

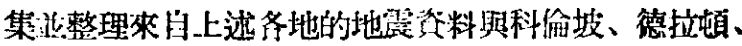

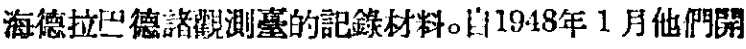

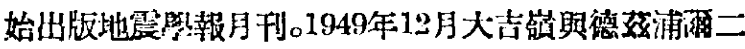
地方各有三次大地祳，在 Rossi-Forel 骤人上均有 5 强 度的記錄。

('Nature' No. 4asi)

\section{Langmiur 氏的人造雨}

得到諾貝河焚金的 1. Longmiur, 在最近的科學襍 誌上發表了以下的綜合報告：

“菑行人造雨，須在適當的料冢狀况下，向適合地

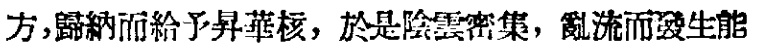
力, 漟是達到初期的目的。沟有昇華核而零要達到所謂

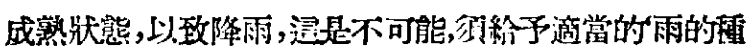

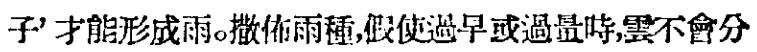
成上下臂，降雨還是荘分全失败。所謂適當的雨的種子，

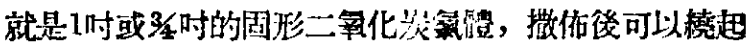

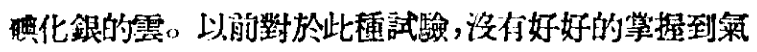

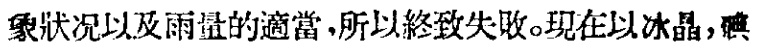
化銀等做雨的程子,人造雨, 可以成功。

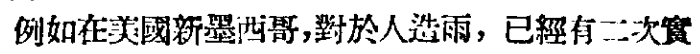

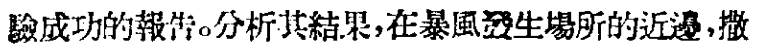

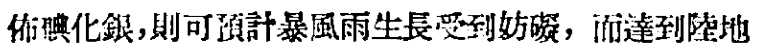

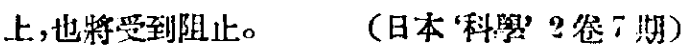

\section{4 皘雨需移動的侢造}

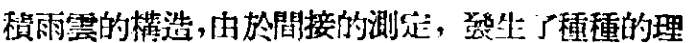

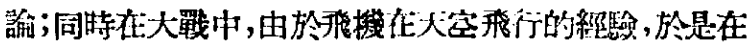


194.6-47年兩年的夏天,美國空莗、海軍、流體力學工作

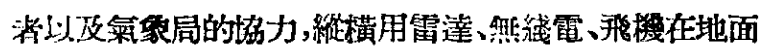

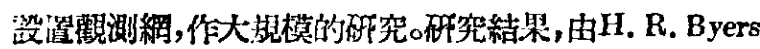

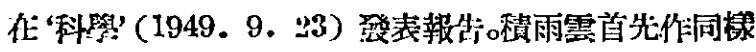

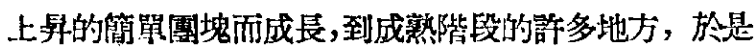

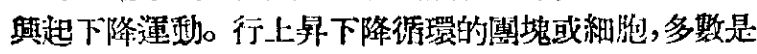

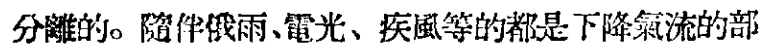

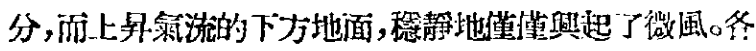

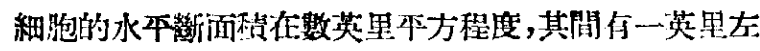

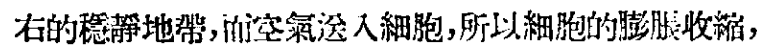
似乎是断熱的。在沿诚谟，首先上等氣流消失，不久下降

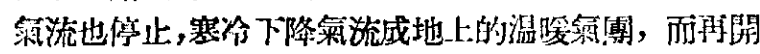
始形成赖雨需。

(日本“科學”200龙 3 期)

\section{2,4-D 可加深馬鈴薯䫓色}

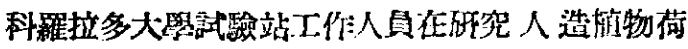

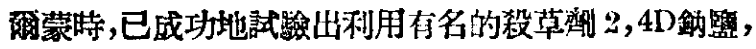
可將 Red Mcclure 攻 Bliss Triumph 程的馬鈴蓦加深 紅頝色，並可增加維他命 C 的含量。其法係當馬鈴慕仍

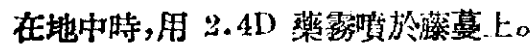

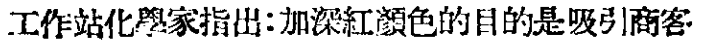
及主婦的注意力,擝加維他命 C 含至至 $12.5 \%$,是供給

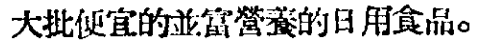

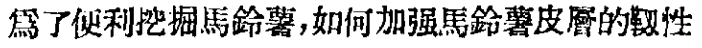
也正在研究中。

('Science News [etter' 1950,10.7.)

\section{6 一種新的抗生物製劑 Diplomycin}

Noster E從1945年起至 1949年7月在一程雙球菌 露提鍊出一種新的抗生物製娜 D i p lom y cin, 在丹 麥的繁院中肘治海過 100 值不同病 例的病人; 發現 Diplomycin的抗菌力作用不管在革蘭氏除性、隄性的微 生物及結核菌中都份隇荿力存在。沼種抗生物作用係由 某種分泌物造成者; 細菌對 Diplomycin 抗拍力, 對

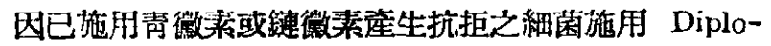

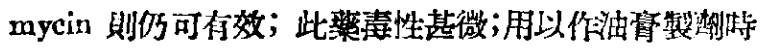

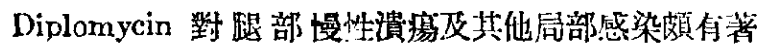

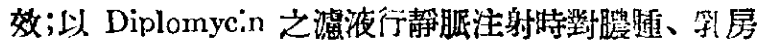

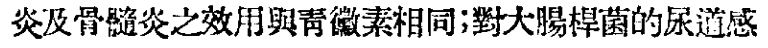

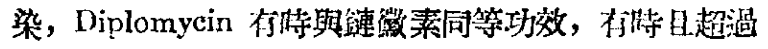

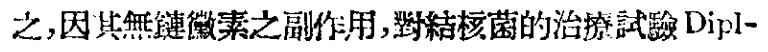
omycin 可流是有希望的。

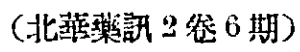

\section{7 箓徽索治療㛝兒急性腸胃炎}

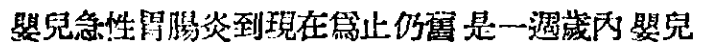
死亡1/3的原因。础胺鸩、青微素及鏈徽素都末能湤足我

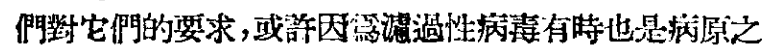
一的關係。英國伯明翰兒童醫院, 在最近入個月中曾以

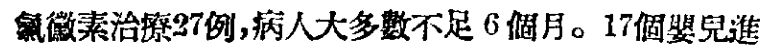

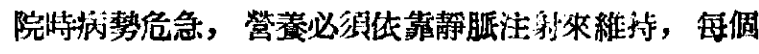

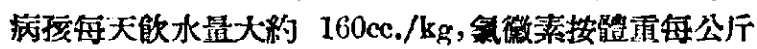

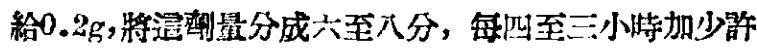

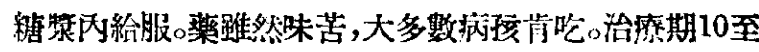

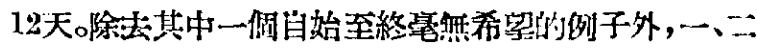

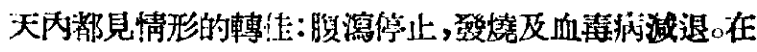
若于例中併的消化道外傳染办在用蔡媵受排制。副作 用如淍身性過症症、過敏性皮處炎等發生的不多而且不

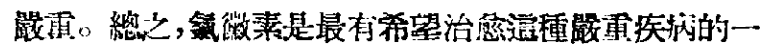
㮔藥江。

(Lancet 19.0. 6604)

\section{8 一種啋維生趐一一維生素乙12b 之性能與醫療功效}

由金微 Streptomyces aureof aciens 提䌘䛔得一㮔

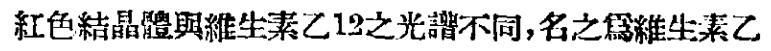

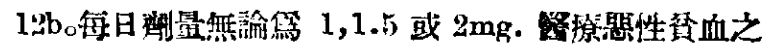

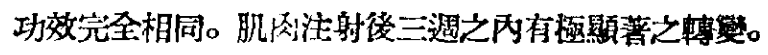

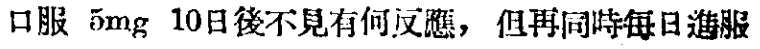

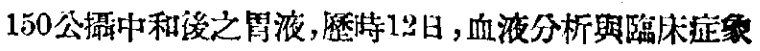

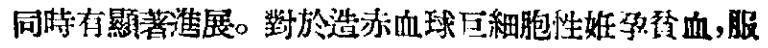

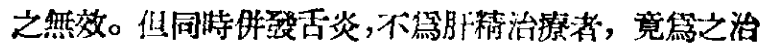
意。此種紅色結晶䁬, 與由肝精中用的酸分析色法法所 得淡紅部份精製而的得之紅色色素相同。

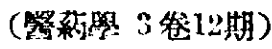

\section{9 腸中細菌合成人體票要之維 生素乙1.2}

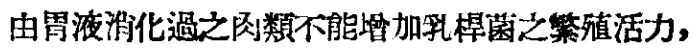
但腸部內容物, 可以使孚桿菌唔加繁殖。自人類, 羊、馬 等腸中取出之域品, 俱有使蚠血恢復之功能, 由其在人

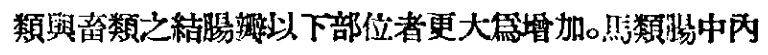
容物更抽取出色素分析之紅色部分，完全與維生素乙19

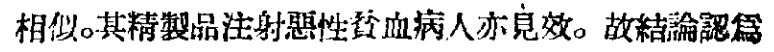

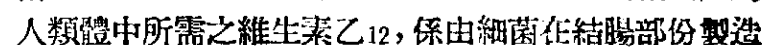
供應者。

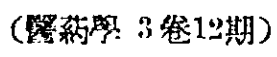

\section{0 肺結核患者指甲的戀化}

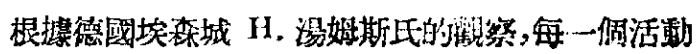

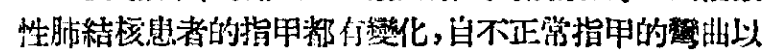

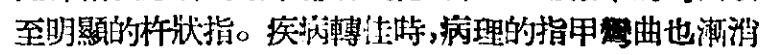
退。這種指甲等化可能是由毒性酸性的盆白筫新陳广謝

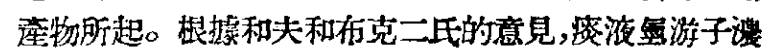

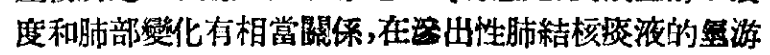
子湴度是較瀻維性更接近酸性,前者的值是 $6.2 .5-5.9$ 後者是 $6.75-6.55$ 。

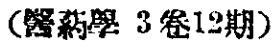




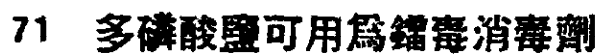

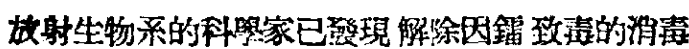

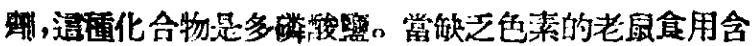
有硝酸第化合物，21天後25隻中即有一隻死掉，45日末

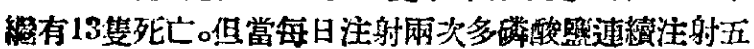
天的25隻老鼠,21天挠沟有一隻死亡，45日末只有一隻

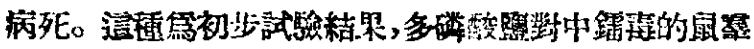
中似存照诸的抗毒性盗。

('Science News Letler' 1950.10.21)

\section{2 羅馬尼亞的很村文化舘}

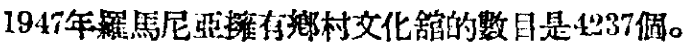

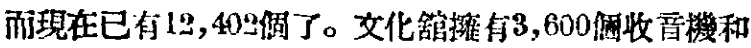

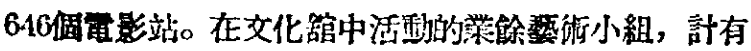
9,800谓，交化舘附設了一曾一下多個圆書颌。

(東北㖘潆 No.21)

\section{3 波蘭科學院在符僃中}

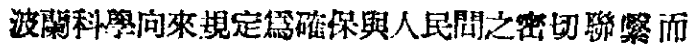

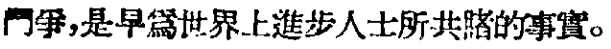

民主的華沙，更造成了對科學創造最腹泛的可能

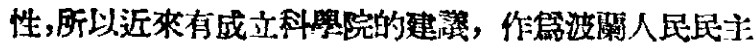
共和國科祭生活的中心。

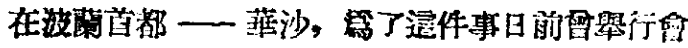
加的教是國內知名的學者。在會撑上討谕了閶於

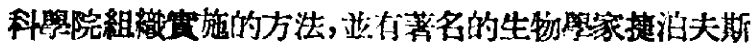
基博士作詳細的冁告。

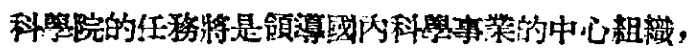

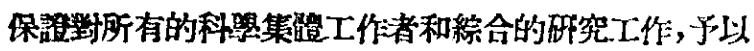

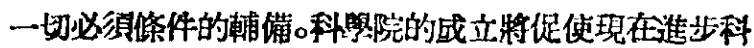
祭的更進一步的發展,渱切結合到人民的需要, 以便在 波得基定共迹主義的基礎。

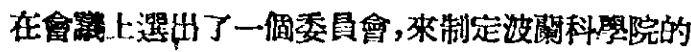
章則與法娧。

（貣理報 1950.12.23）

\section{4 阿两巴尼亞的大學}

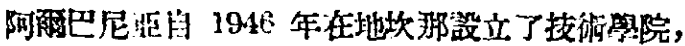

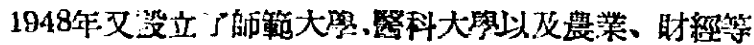

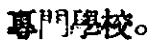

(光明月坯 1 月11日)

\section{5 印度國立化學研究所}

印度計劃設立11偑國立科學技河研究所，其第七國

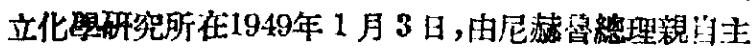

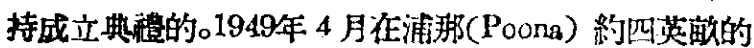

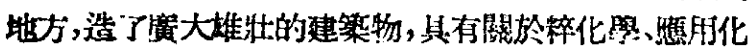

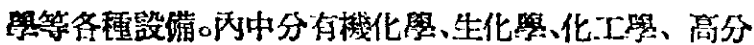

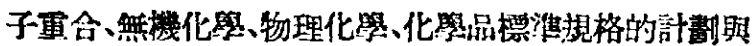

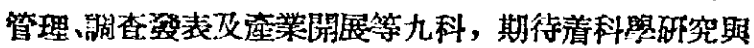

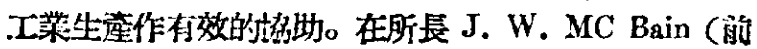

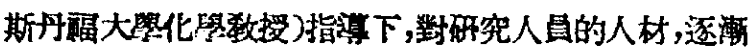

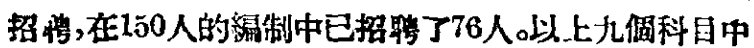

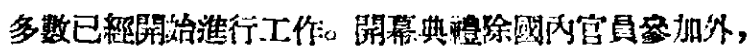
還有許多國外科照工作者; 闰保 R. Robinson A. H. Compton Irene Joliot-Curie 仗 C. V. Raman 等加 邀㑬盛會。

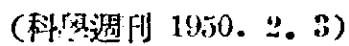

\section{6 日本大學校舍將變虚兵營}

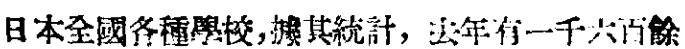

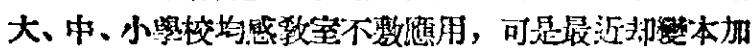

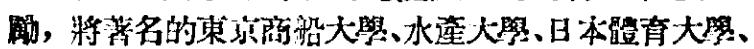

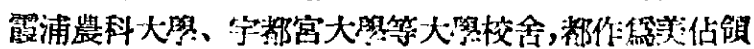

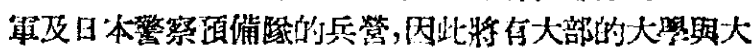

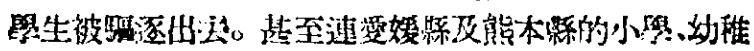
㩆也旅伤兵管了。

(日本“科學者”非响)

\section{7 生物科客國際聯會}

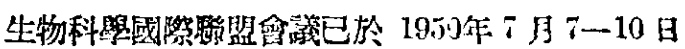

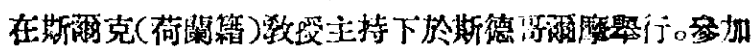

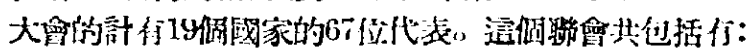

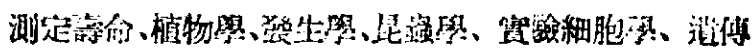

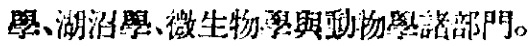

$$
\text { ('Nature' No. 4225) }
$$

\section{8 第五屆國際微生物孟拿議}

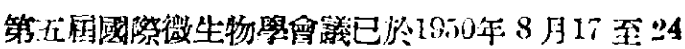

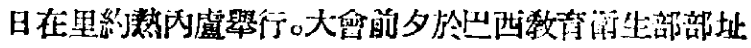

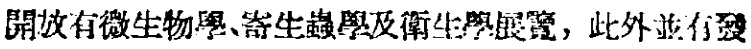

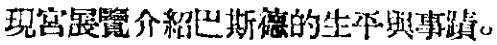

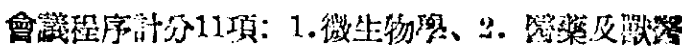

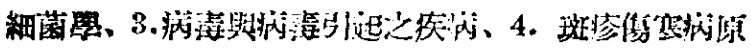

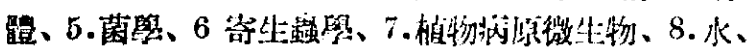

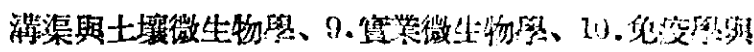

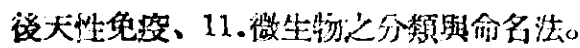

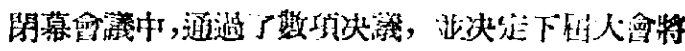

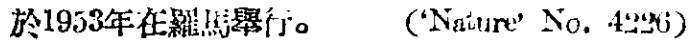

\section{9 第五屆國際澏腫合蓄}

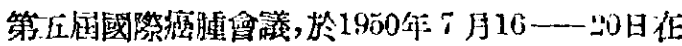

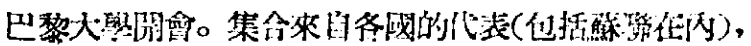

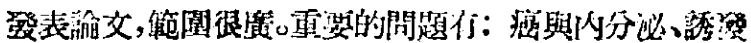

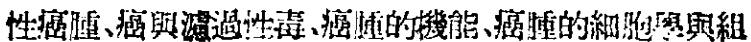

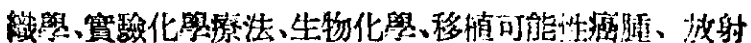

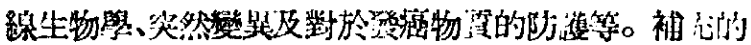

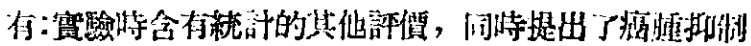

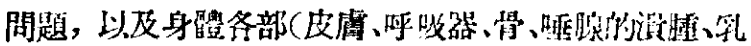

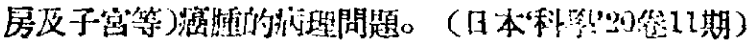

\section{0 放射生物學混合委員俞}

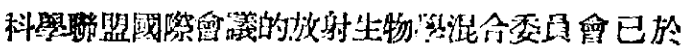

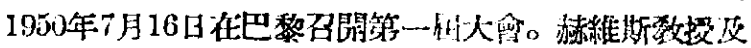

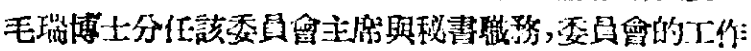

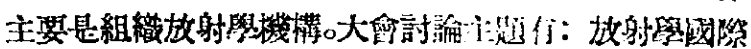

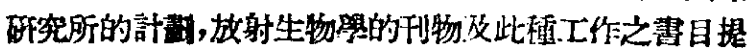




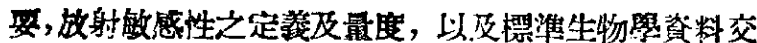
換的可能性等。最後並决定組成分組委員佥研討第一、 三項雨問影。

('Nature No.4236)

\section{1 第十一屆理論、應用湖沼學 國際命議}

17國的 89 位代表已參加了在比利特码開的第11国

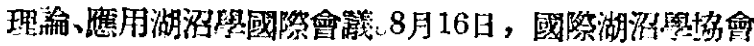

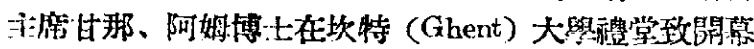

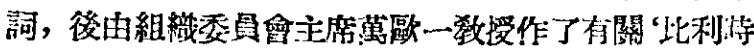

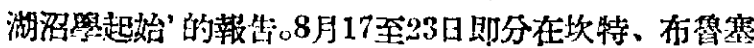

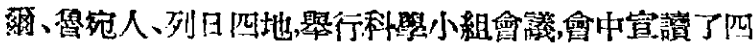
十餘件諭文。值得提出的計有：晹姆斯(祖力克)㙛七的

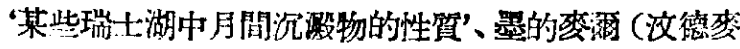

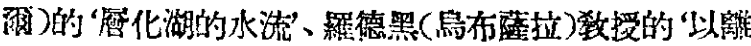
子互换提出、分析湖水法”、樂非伏濔(法國)的“淡水藻類 縋承䓋間的不容性”、安古那(巴杜阿)教授的“威尼斯河

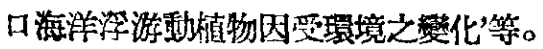

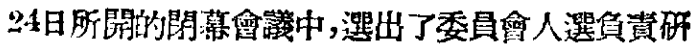
究水生生物調查的激方法; 亚决定下次大會將於1953年 在众橋舉行。

('Nature' No. 4225)

\section{2 世界動力大會分區會議}

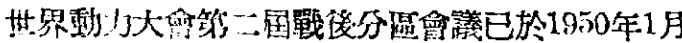

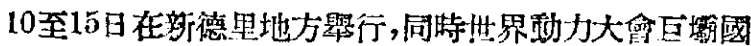
除委員會亦召開其第四屆大會，灌溉、渾河國際委員會

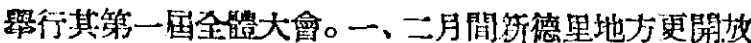

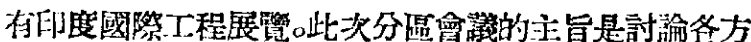

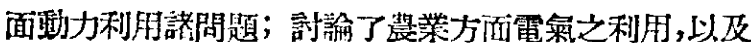
工業發展與行力炎源登展的配合問題。各種大會的閉幕

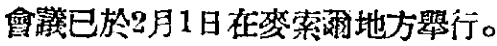

(Nature' No. 4226)

\section{3 波菏物理學會}

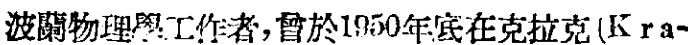

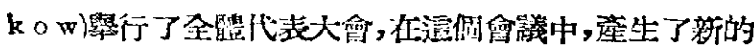

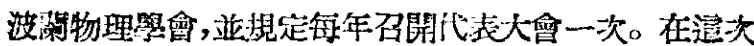

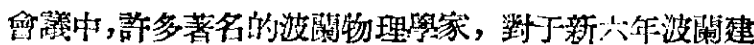

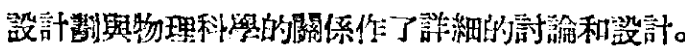

('Polish Bullelin' No.26)

\section{4 第一屆全波蘭興改水利會議}

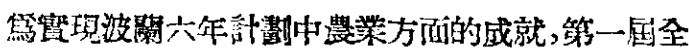

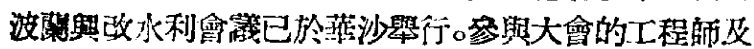

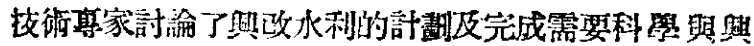

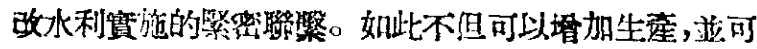

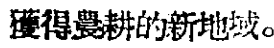

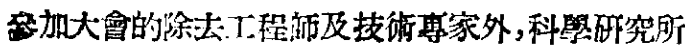

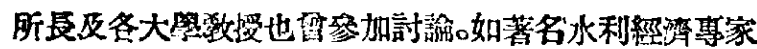
飘司趋美斯基 (Ostrimecki)和聖瓦司 (St. Bac) 教授等

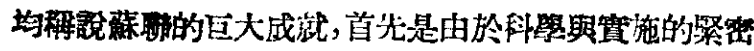
接合。

('Polish Bulletin' No.24)

\section{5 北歐地朢學金}

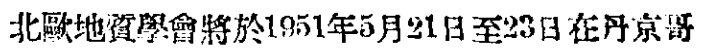

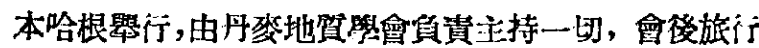
六日，將分三組：1.赴法克些、斯弟芬及梅恩 (Fakse。

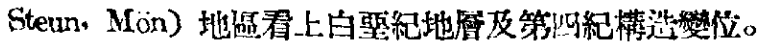

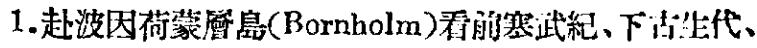

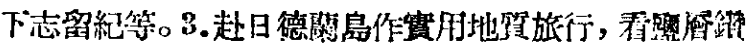

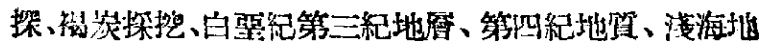
賀作用期碼頭起築等等。

(陳光逯)

\section{6 匈牙利科學院 125 週年紀念 大會}

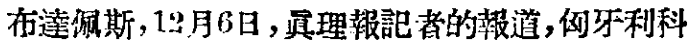

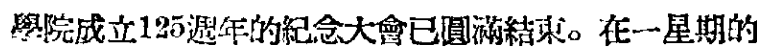

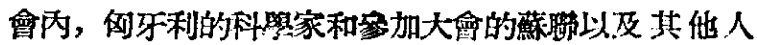
民民主国家的科累家討論了許多重努的科學七的問題。

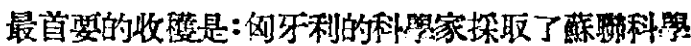
家的榜樈，已經把他們的科照事業，建立在䮃克思一列

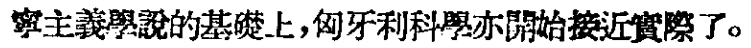

在會議上還現示了匈牙利科嘿冢在人交科學方面 的絕偗的成功。

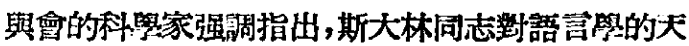
专創作，光政地指示了大會上語言舆交學部門以及社會

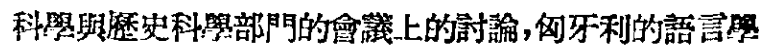

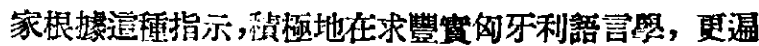
皮所有的刚牙利科祭。

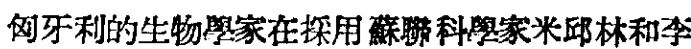
森科的登明以及維里耶姆思的牧草誈, 都獲得了成功。

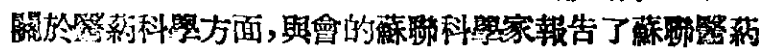
上的成就, 以及對於䦽些成就的利用。

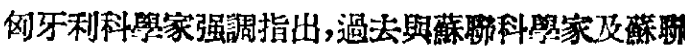

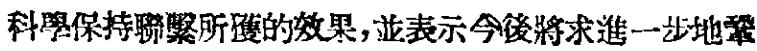
国造種証絮。

大俞閉幕日，全體與會人員通過了向现代最借大的 科學家斯大林同志致敬的電文。（而理報1950.12.7.)

\section{7 澳洲海洋淡水研究學報}

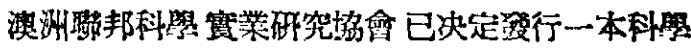

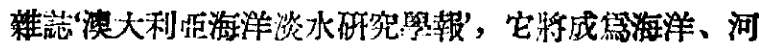

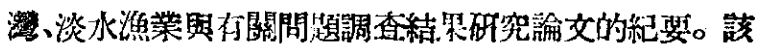

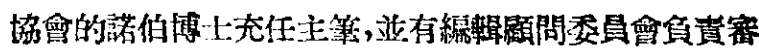
查稿件。興報係不定期们物，乃焦適當材料的總和;每年

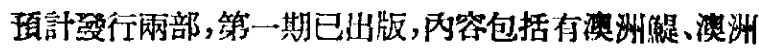
梭魚漁業没雪梨牡物之法落等。

('Nature' No. 4226)

\section{8 美國科學家人名錄第八版已 出版。}

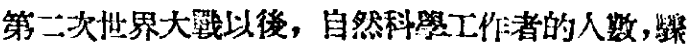
然坦加,美國科礐家名錄(Americnn men of Science)第 入版已於1950年出版，淁集所收知的人教，大政已有 52,600人之多。

(日本“科學20贷11期)
第一期
科學通報
- 213 • 


\section{南京市組成志願醫療團}

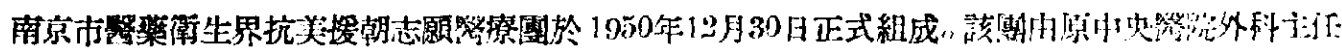

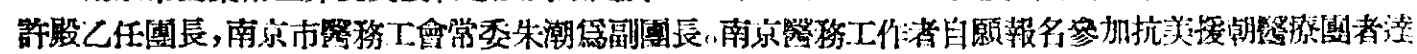

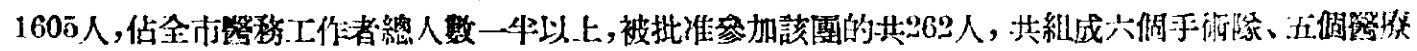

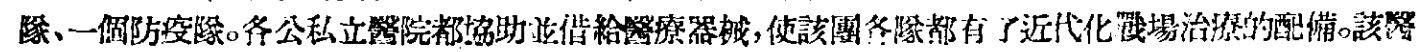

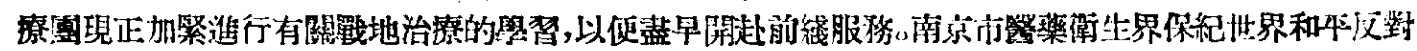

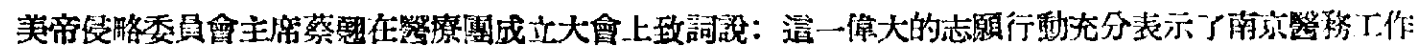

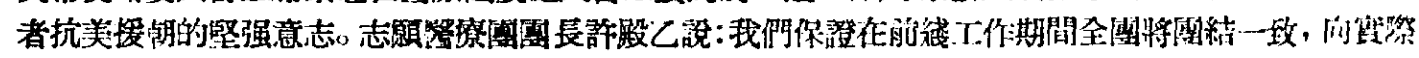

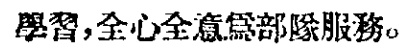

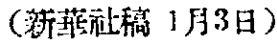

\section{長沙抗美援朝志願醫療手術 榢首批二十七人已經出發}

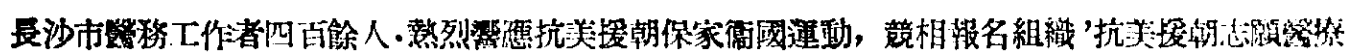

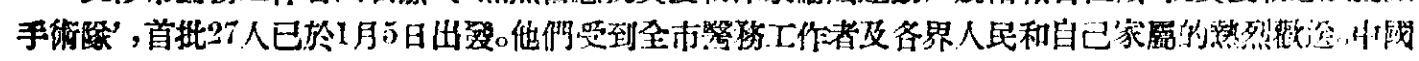

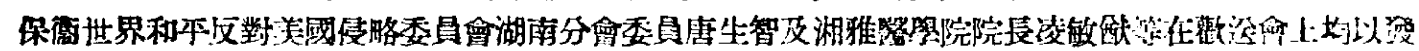

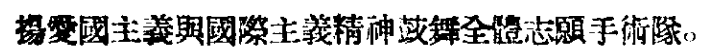

(新烡站稿 1 月10日)

\section{江西省首批志願赴朝手術隊出㻐}

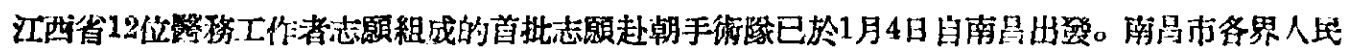

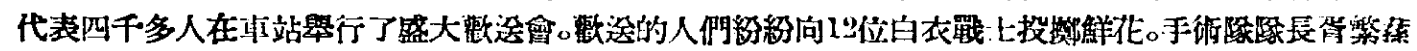

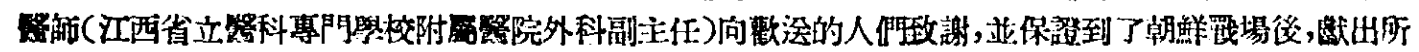

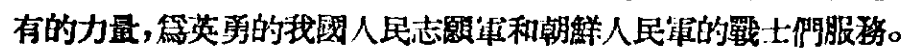

（新免社稿 1 月8日）

\section{廣州中山大學醫學院師生組 成志願手術榢赴朝工作}

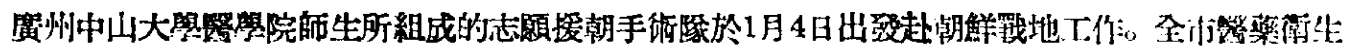

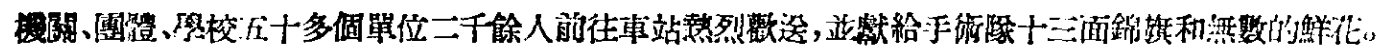

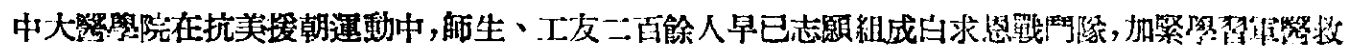

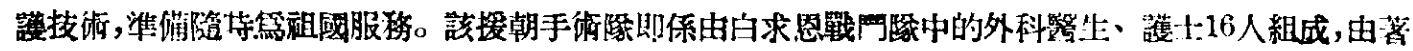

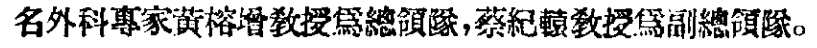

(新華社榜 1 月 10 日)

\section{川西第二醫院組成援朝醫療隊}

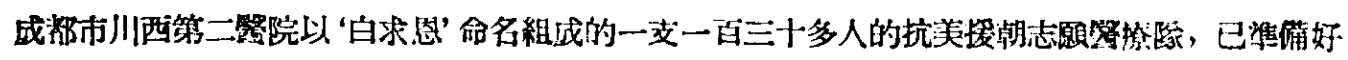
前往朝解前継服務。

（陭新華日報 1) 月13日） 